\title{
Inconsistent descriptions of lumbar multifidus morphology: A scoping review
}

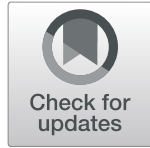

Anke Hofste ${ }^{1,2^{*}}$, Remko Soer ${ }^{1,2}$, Hermie J. Hermens ${ }^{3,4}$, Heiko Wagner ${ }^{5}$, Frits G. J. Oosterveld ${ }^{2}$, André P. Wolff ${ }^{1}$ and Gerbrand J. Groen ${ }^{1}$

\begin{abstract}
Background: Lumbar multifidus (LM) is regarded as the major stabilizing muscle of the spine. The effects of exercise therapy in low back pain (LBP) are attributed to this muscle. A current literature review is warranted, however, given the complexity of LM morphology and the inconsistency of anatomical descriptions in the literature.
\end{abstract}

Methods: Scoping review of studies on LM morphology including major anatomy atlases. All relevant studies were searched in PubMed (Medline) and EMBASE until June 2019. Anatomy atlases were retrieved from multiple university libraries and online. All studies and atlases were screened for the following LM parameters: location, imaging methods, spine levels, muscle trajectory, muscle thickness, cross-sectional area, and diameter. The quality of the studies and atlases was also assessed using a five-item evaluation system.

Results: In all, 303 studies and 19 anatomy atlases were included in this review. In most studies, LM morphology was determined by MRI, ultrasound imaging, or drawings - particularly for levels L4-S1. In 153 studies, LM is described as a superficial muscle only, in 72 studies as a deep muscle only, and in 35 studies as both superficial and deep. Anatomy atlases predominantly depict LM as a deep muscle covered by the erector spinae and thoracolumbar fascia. About $42 \%$ of the studies had high quality scores, with 39\% having moderate scores and 19\% having low scores. The quality of figures in anatomy atlases was ranked as high in one atlas, moderate in 15 atlases, and low in 3 atlases.

Discussion: Anatomical studies of LM exhibit inconsistent findings, describing its location as superficial (50\%), deep $(25 \%)$, or both (12\%). This is in sharp contrast to anatomy atlases, which depict LM predominantly as deep muscle. Within the limitations of the self-developed quality-assessment tool, high-quality scores were identified in a majority of studies (42\%), but in only one anatomy atlas.

Conclusions: We identified a lack of standardization in the depiction and description of LM morphology. This could affect the precise understanding of its role in background and therapy in LBP patients. Standardization of research methodology on LM morphology is recommended. Anatomy atlases should be updated on LM morphology.

Keywords: Paraspinal Muscles, Lumbar Vertebrae, Lumbar multifidus, Erector spinae, Magnetic Resonance Imaging, Ultrasonography, Computer Tomography, Scoping review, low back pain

\footnotetext{
* Correspondence: r.soer@umcg.nl

${ }^{1}$ Anesthesiology Pain Center, University of Groningen, University Medical

Center Groningen, Location Beatrixoord, Dilgtweg 5, Haren, the Netherlands

${ }^{2}$ Faculty of Physical Activity and Health, Saxion University of Applied

Sciences, Enschede, the Netherlands

Full list of author information is available at the end of the article
}

(C) The Author(s). 2020 Open Access This article is licensed under a Creative Commons Attribution 4.0 International License, which permits use, sharing, adaptation, distribution and reproduction in any medium or format, as long as you give appropriate credit to the original author(s) and the source, provide a link to the Creative Commons licence, and indicate if changes were made. The images or other third party material in this article are included in the article's Creative Commons licence, unless indicated otherwise in a credit line to the material. If material is not included in the article's Creative Commons licence and your intended use is not permitted by statutory regulation or exceeds the permitted use, you will need to obtain permission directly from the copyright holder. To view a copy of this licence, visit http://creativecommons.org/licenses/by/4.0/. The Creative Commons Public Domain Dedication waiver (http://creativecommons.org/publicdomain/zero/1.0/) applies to the data made available in this article, unless otherwise stated in a credit line to the data. 


\section{Background}

Stabilizing therapy through muscle training is one of the main physiotherapeutic interventions for low back pain [1-3]. A uniform theoretical background for this treatment is lacking [4], however, and more recent studies report contradictory results following this treatment [5-7]. There are no explanations for how stabilizing therapy could have such opposing effects on patients with low back pain. Given that the lumbar multifidus (LM) is regarded as the major stabilizing muscle of the spine [5, 8-14], the anatomy and topography of this muscle might offer at least some explanation for the opposing effects of stabilizing therapy.

The morphology of the LM is complex, and several anatomical descriptions have appeared in the literature [15-19]. Anatomical studies have concluded that the LM has the largest cross-sectional area (CSA) of paraspinal muscles with short levers located at the most medial part of the spine between approximately L4 and S1 [16, 20, 21]. Important factors in spinal stabilization include CSA, deformation or stress in ligaments, and muscle type, activity pattern, force, mass, and length [8-10, 19, 22]. According to other studies, however, LM muscle mass is too small to play a substantial stabilizing role, and the primary stabilizing role should be attributed to the erector spinae (ES) [4]. Furthermore, an ongoing debate concerns the topography of the LM to the ES (i.e., deep vs superficial) [19, 23-25]. This discussion has led to many different approaches to investigating the morphology and functional characteristics of the LM. For example, LM muscle morphology has been quantified through ultrasound imaging (USI), MRI scanning, CT scanning, surgery, biopsy, and cadaver research. The outcomes of these methods have led to varying conclusions about CSA, muscle thickness, percentage of fat infiltration, fiber-bundle angle, and fiber length [19, 26-29]. Although each method has its own strengths and limitations [30], the results also depend on other variables, including population, spine-level measurement, and methodological quality.

At present, there is no clear overview of the similarities and differences between anatomy atlases and LM topography studies with regard to LM topography in humans. Such an overview is essential to improving understanding concerning the theoretical background of stabilizing therapies in the treatment of low back pain, as well as with regard to its role in basic anatomy training. The present study is therefore intended to review the literature on LM morphology.

\section{Materials and Methods}

This study was conducted according to the guidelines formulated by Arksey and O'Malley 2005 and by Grudniewicz et al. 2016 [31, 32], using the following five-step framework: (1) identification of the research question,
(2) identification of relevant literature, (3) study selection, (4) data extraction, and (5) collation, summary, and reporting of results. The identification of the research question (1) is explained in the Background section. Steps 2, 3, and 4 are explained in this Materials \& Methods section, and Step 5 is discussed in the Results section.

\section{(2) Identification of relevant literature Search strategy}

To identify relevant studies on LM morphology, two databases-PubMed (Medline) and EMBASE-were searched, as well as gray literature (anatomy atlases) until June 2019. Search strategies were built, consisting of a combination of database-specific MeSH terms, title/ abstract, free text, "wild cards" (words truncated by using “"”), and Boolean operators ("AND”, "OR”). The search string is provided in Additional file 1. The snowball method was used to identify additional papers from the reference lists of studies that were included.

\section{Eligibility}

All of the studies included were reviewed in terms of population, method, and outcome. To be included, studies had to be published in English and be based on studies of adult humans or human cadavers. A supplemental search of the Dutch literature did not reveal any relevant studies. Letters to the editor, abstract-only articles, and review papers were excluded. The initial search identified an extensive number of studies and gray literature. To minimize the inclusion of low-quality studies, we limited inclusion to peer-reviewed studies. All of the studies included were screened for the methods used to measure LM morphology: USI, MRI, CT scanning, modeling (biomechanical model of muscles), and cadaver studies. Furthermore, the parameters by which LM morphology was defined were described for each study (i.e., images, photos, drawings, models, trajectory descriptions, thickness or CSA, spine levels, and location of the LM).

\section{(3) Study selection}

The selection procedure started with the identification of studies in the databases and the elimination of duplicates using the duplicate function in Endnote X9. Further, studies were screened according to title, abstract, and full-text, and additional papers were identified from reference lists of the included studies. Two authors $\mathrm{AH}$ and RS) independently selected and assessed studies for quality and subsequently discussed them to reach consensus. When no consensus was achieved, a third reviewer was consulted (GJG).

Anatomy atlases were included as well, given their importance as basic anatomical introductions to LM 
topography. The anatomy atlases were selected through a university library system, followed by a snowball procedure, as they were not included in medical databases. Major anatomy atlases available in English, Dutch, and German were retrieved from the university libraries (including specialized medical libraries) of the University Medical Center Groningen and Saxion University of Applied Sciences, as well as from online resources. The results of anatomical studies and atlases are presented separately.

\section{(4) Data extraction}

All studies and atlases were extracted according to the following LM parameters: location (deep/superficial), imaging methods, spine levels, muscle trajectory (origin and insertion), muscle diameter (anteroposterior diameter), and CSA. The risk of bias assessment was not determined, as it primarily has to do with the methodology of studies [33]. Instead, a quality-assessment tool was developed to rate the quality of the descriptions of LM morphology. The tool consists of five items, each worth one point, with a maximum score of five (Table 1). The reliability of LM morphology descriptions was assessed by checking for the presence of an image and determining whether this image was an original photograph (as opposed to a model or drawing) [34]. Furthermore, the validity of the images was assessed by checking for the labelling of the LM, depiction of spinal levels, and description of planes. Descriptions scoring 5/5 were regarded as being of high quality, with scores of (3-4)/5 representing moderate quality and scores $(\leq 2) / 5$ representing low quality. The inter-rater reliability (\% agreement) of the two reviewers was calculated using a kappa value. In cases where the LM location was not described explicitly despite the presence of adequate imaging, the LM location was determined in consensus by the authors (AH, RS and GG).

\section{Results}

\section{Study selection}

The search yielded 2450 original studies, 299 of which were ultimately included, along with 4 additional studies. In addition, 19 anatomy atlases were identified that described parameters of LM morphology (Additional file 2) $[25,55-67]$. The study-selection procedure is depicted in Fig. 1.

\section{LM parameters in studies}

The characteristics of the studies included are presented in Additional file 3 [17-20, 22, 26, 27, 29, 34-37, 39-53, $71-80,82-343]$. In descriptions of moderate to high quality, the most frequently applied methods for measuring or visualizing LM morphology were MRI (51\%), USI (36\%), and drawings (8\%).

\section{Location}

In 153 of the 303 studies, LM was presented only as a superficial muscle at one or more levels between L4-S1. In 72 studies, it was presented only as a deep muscle and, in 35 studies, it was presented as both a superficial and a deep muscle. We were unable to identify the precise location of LM in 43 studies (Additional file 3).

\section{Origin and insertion}

The origin of the LM is described at the spinous process of L4 and L5 [35]. In some studies, however, LM origin was also described at the caudal and dorsal surface of each lamina (L1-L5) (Table 2) [23]. Whereas some studies described LM insertion as being at the lateral or medial side of the dorsal foramen of the sacrum $[23,35]$, others stated that the superficial LM muscle fibers are inserted at the posterior superior iliac spine (PSIS) $[19,23]$.

\section{Muscle thickness and cross-sectional area (CSA)}

We identified a variety of methods of measuring the CSA of LM. These methods include USI, CT scanning, and/or MRI at various levels of the lumbar spine (Additional file 3) between L1 and S1 (Fig. 2). This focus on L4 and L5 measurements was found in nearly all studies on different locations (Fig. 2).

The CSA of LM has been measured in a variety of populations, resulting in an extensive range of LM CSA outcomes $[27,47,48]$. The total range in square millimeters varied between 9.08 and $2500 \mathrm{~mm}^{2}$, possibly due to the incorrect description of corresponding units of

Table 1 Quality assessment tool

\begin{tabular}{|c|c|}
\hline Item & Meaning of score \\
\hline 1 Image present & $1=$ yes $; 0=$ no \\
\hline 2 Quality of image & $\begin{array}{l}1 \text { = sufficient (unambiguous for lumbar multifidus by MRI, photo, dissection, } C T \text {, ultrasound or biopsy) } 0=\text { insufficient } \\
\text { (tenuous for lumbar multifidus by modeling or drawing) }\end{array}$ \\
\hline 3 Clear labeling of LM & $1=$ yes $; 0=$ no \\
\hline $\begin{array}{l}4 \text { Presence of spine levels } \\
\text { depicted }\end{array}$ & $1=$ yes $; 0=$ no \\
\hline 5 Description of plane & $1=$ yes $; 0=$ no \\
\hline
\end{tabular}




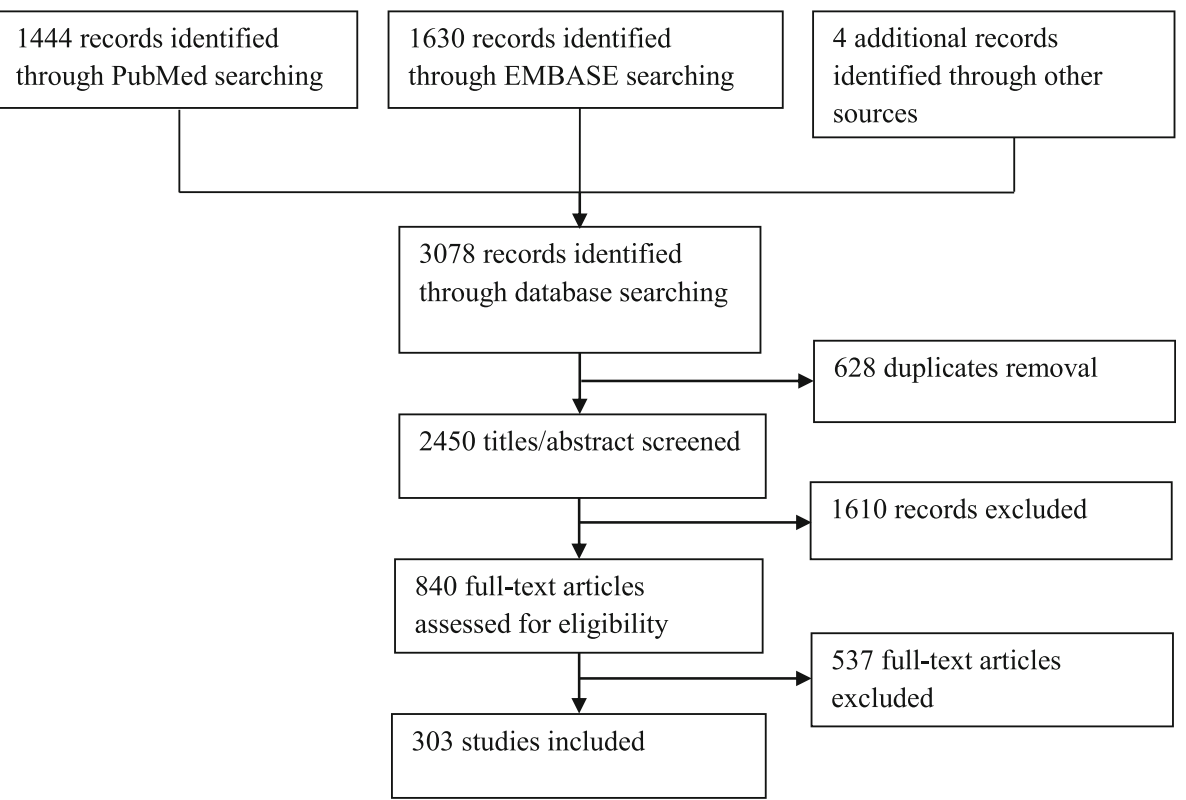

Fig. 1 Flowchart of the selection process for the literature review

value. Variations in LM thickness were found with regard to the level of measurement (L3/L4, L4/L5, or L5/ S1) and LM activation conditions (rest vs (sub)maximal voluntary contraction), as well as in terms of body position (e.g., prone vs standing position) (Additional file 4) $[38,47-53,51-53,74,75,98,108,113,115,127,131$, $135,136,144,151,159,162,163,168,175,187,203$, $211-213,233,235,236,239,253,259,263,286,301$, $305,308,309,311,317-322,325,326,335,336,340]$ [48-53]. The total range in LM thickness in millimeters varied between 2.4 and $41.1 \mathrm{~mm}[53,54]$.

\section{LM parameters in anatomy atlases}

Within the anatomy atlases, we observed variations in the description and presentation of LM (Table 5), although the majority of atlases showed the same configuration of the LM. In 16 of the 19 atlases reviewed, the LM was depicted as a deep back muscle [24, 25, 55-62, 64-71], either covered by the thoracolumbar fascia and/ or as being covered by the ES. Moreover, LM imaging varied in terms of the presence of spine levels (cervicalsacrum), imaging planes (transversal, dorsal, sagittal), and of whether it was with or without other low back muscles in a single figure.

\section{Location and muscle diameter}

Variations were found with regard to the location, diameter, and topography of the LM. In one anatomy atlas (Gray's Anatomy) [61], the superficial part of the LM extended from T11 cranially to S3 caudally as a wide (large anterior-posterior diameter) muscle next to the median sacral crest. In a Radiology Anatomy Atlas Viewer [63], the LM was depicted in the axial spinal cross-sections, albeit with inconsistent labelling of the LM.

Variations were found in the diameter of the LM between the various lumbar levels. The location of the widest part of the LM varied between the level of PSIS [55, $58,60,61]$ and L5-S1 $[25,56,57,69]$. In some atlases, however, the widest part of the LM was undefined, due to the overlying low back muscles [24,67].

Various origins and insertions of the LM were identified in the anatomy atlases (Table 3), with the (lumbar) multifidus extending between the dorsal part of the sacrum [69] and the transverse processes of $\mathrm{T} 1[24,25$, $55-58,60,65,67,70,71]$, and as attaching to the iliac $[68]$ or ischium $[55,60]$ part of the pelvis.

Overall, deep LM trajectories were consistently described between L1 and S5 [25, 56-58, 60, 61, 67, 70], although some superficial LM fibers were illustrated as originating from the spinous process of T10 [69] or T12 $[61,70]$. Furthermore, some atlases did not illustrate the origin and insertion of the LM, as other muscles were more superficially presented and/or because these features were not described $[24,59,62,64,66,68]$.

\section{Quality assessment}

Quality scores were determined for each description and anatomical image of the LM in the literature. The peritem quality scores for descriptions and anatomical images are presented in Table 4. The agreement between the reviewers of the quality assessment had a kappa value of 0.67 , and all differences were resolved in a 
Table 2 Studies describing the fiber trajectory of LM

\begin{tabular}{|c|c|c|c|c|}
\hline Author year & Method $^{1}$ & $\begin{array}{l}\text { Spine } \\
\text { Level }\end{array}$ & $L^{2}$ & Fiber trajectory of $L M$ \\
\hline $\begin{array}{l}\text { [26] Beneck } \\
2012\end{array}$ & 1 & L4-S1 & S & The LM morphology best captures span the L4-L5 or L5-S1 functional spinal units \\
\hline $\begin{array}{l}\text { [35] Bogduk } \\
1992\end{array}$ & 6 & L5-S1 & $U$ & $\begin{array}{l}\text { LM origin is tip or shaft of spinous process L1-L5. LM insertion is medial and lateral next to the posterior } \\
\text { sacral foramen }\end{array}$ \\
\hline $\begin{array}{l}\text { [36] Bojadsen } \\
2000\end{array}$ & 4 & $\mathrm{~T} 1-\mathrm{S} 1$ & $\mathrm{D}$ & $\begin{array}{l}L M \text { insertion at the spinous process of } L 5 \text { and of } T 12 \text { and } T 11 \text { contains vertical fibers. The most caudal } \\
\text { fibers of } L M \text { run a vertical trajectory between the medial portion of the sacrum and the spinous process } \\
\text { of } L 5 \text {. }\end{array}$ \\
\hline $\begin{array}{l}{[37] \text { Creze }} \\
2017\end{array}$ & 2,4 & L3 & $\begin{array}{l}D \& \\
S\end{array}$ & $\begin{array}{l}\text { On the first inspection, the multifidus represented a homogenous muscular mass with a triangular shape. } \\
\text { It comprised many millimetric tendinous and fleshy fascicles originating from the spinous processes to } \\
\text { the mammillary processes located 1-3 spinal levels above. The muscular organization was unclear and } \\
\text { the multifidus appeared as a multiceps and multipennate muscle. Multifidus fascicles were arranged in } \\
\text { three or four layers from superficial too deep with few or no cleavage planes between them. Some } \\
\text { interdigitations attached fascicles between them. For each lumbar level, the muscular fascicles and fibers } \\
\text { were oriented from } 98 \text { to } 228 \text { to the line of spinous processes. }\end{array}$ \\
\hline
\end{tabular}

$\begin{array}{lll}\text { [38] Creze } & 4 & - \\ 2018\end{array}$

$S$ The ES aponeurosis (ESA) had different anatomical relationships with the longissimus, the iliocostalis, and the LM. Along the lumbar and sacral regions, close to the SPL medially, some muscle fibers of superficial fascicles of the LM were attached directly (without pennation) to the ESA. Each fascicle of the LM (i.e., the group of muscles originating from a spinous process) was covered by a thin pearly white aponeurosis corresponding to a fascial expansion of the cranial attachment on the spinous process. Connectives fibers were all oriented longitudinally along the muscle belly. The thickness of the LM aponeurosis decreased along the rostrocaudal axis of each fascicle and was too thin to be measured with the material used. Connective fibers of the LM aponeurosis were oriented parallel to the longitudinal axis of the fascicle.

$\begin{array}{lll}\text { [39] Creze } & 4 & - \\ 2019 & & \\ \text { [40] De Foa } & 4 & \text { L1-L2 } \\ \text { 1989 } & & \\ \text { [41] Jemmett } & 4,5 & \text { L2-S } \\ 2004 & & \end{array}$

S The cranial attachment was located on the spinous processes and caudal attachments on the mammillary processes of the three to four vertebras below, the sacrum and on the ESA. There was no tendon at the level of the sacrum, but there were aponeuroses as well as muscle fibers.

1-L2 D LM fibers run parallel to a line between the posterior superior iliac spine and the L1-L2 interspinous space

D \& The superficial LM fibers of the first fascicle of the LM originated at the caudolateral tip of the L1 spinous

$S$ process. The deep LM fibers of the first fascicle originated from the caudolateral base of the L2 spinous process. This first fascicle inserted at the mamillary process and lamina of $L 4$ as well as the capsule of the L4/5 zygapophysial joint and the most cranial aspect of the PSIS. The second fascicle originated in the same manner from the L2 andL3 spinous processes and inserted near the PSIS and just adjacent to the superior articular process of $\mathrm{S} 1$.
[42] Kader 1 L3-S1 S LM consists of five separate bands, each originating from a spinous process and spreading caudolaterally 2000 from the midline to be inserted into the mammillary processes of the facet joints, the iliac crest, and the sacrum. In an axial MR image the LM is displayed as two, three or four bands, depending on the level of the image

\begin{tabular}{|c|c|c|c|c|}
\hline [18] Kim 2015 & 6 & L1-L5 & $\mathrm{D}$ & LM consists of laminar fibers, fascicles from the shaft and from the tip of the spinous process. \\
\hline [43] Kramer & 1,5 & - & S & $L M$ activity was measured with EMG at the level of the vertebral body of $L$ 2. \\
\hline
\end{tabular}

[44] Macintosh $\quad 4,5$
1986

[19] Moseley $\quad 2,5 \quad\llcorner 4$ 2002

L1-L5 D \& The principal fascicles of the LM arise as a common tendon from the tubercle and from the lateral $\mathrm{S}$ surface of the caudal edge of the spinous process. The caudal attachments of these fascicles are the mammillary processes, the iliac crest and dorsal surface of the sacrum

D \& LM EMG: The first electrode was inserted $\pm 4 \mathrm{~cm}$ lateral to the midline and directed medially until it $S$ reached the lamina to make recordings from the $L M$ fibers immediately adjacent to the lamina of $L 4$, most likely those arising from the inferior edge of the L3 spinous process (i.e., deep multifidus). The second electrode was inserted $\pm 4 \mathrm{~cm}$ from the midline and advanced to a depth of approximately 1 $\mathrm{cm}$, medial to the lateral border of LM, to record the superficial LM fibers that arise from the upper lumbar vertebras. The third electrode was inserted $\pm 2 \mathrm{~cm}$ lateral to the midline and advanced until it reached the spinous process $\pm 1 \mathrm{~cm}$ from the superficial border of $L M$ to record the superficial fibers of $L M$ adjacent to the $L 4$ spinous process

[45]
Lonnemann 2008

D \& The superficial LM layer originated from the mamillary process to insert onto the tip of two spinous $S$ processes and supraspinous ligaments at the same vertebral level and one above. Tendinous slips and muscle tissue extended dorsally to the overlying ES aponeurosis. The second LM layer originated from the posteroinferior lateral aspect of the spinous processes as a common tendon. The third LM layer originated from the lateral aspect of the inferior aspect of the spinous processes as a muscular band of origin.

D \& Superficial LM fibers originate via a common tendon from the tips of the spinous processes (L1-L5) and 
Table 2 Studies describing the fiber trajectory of LM (Continued)

\begin{tabular}{|c|c|c|c|c|}
\hline 2008 & & & S & $\begin{array}{l}\text { pass inferolateral to the mammillary processes of } L 5, S 1 \text {, sacrum, and ilium. Intermediate } L M \text { fibers } \\
\text { originate from the spinous processes of } L 1-L 4 \text {. Distally, } L 1, L 2 \text {, and } L 3 \text { portions attach as tendons to the } \\
L 4 \text {, } L 5 \text {, and } S 1 \text { mammillary processes, respectively. However, the } L 4 \text { portion attached to the sacrum at the } \\
\text { S2 level. The deep } L M \text { contains five entirely muscular segments ( } L 1-L 5) \text {. Each segment attached } \\
\text { superiorly to the lamina of } L 1-L 5 \text {, and inferiorly two levels more caudal to the } L 3, L 4, L 5 \text {, and } S 1 \\
\text { mammillary process, respectively, while the } L 5 \text { fascicle attached to the sacrum }\end{array}$ \\
\hline [46] Vialle 2005 & 4 & $L 4-L 5$ & S & $\begin{array}{l}\text { An anatomical cleavage plane between } L M \text { and the longissimus part of the sacrospinalis muscle is } \\
\text { present. The level of the natural cleavage plane between } L M \text { and longissimus was noted and measured } \\
\text { between this level and the midline at the level of the spinous process of } L 4\end{array}$ \\
\hline [22] Ward 2009 & 4,5 & $\mathrm{~T} 12-\mathrm{S} 1$ & $\begin{array}{l}D \& \\
S\end{array}$ & $\begin{array}{l}\text { LM was identified by its position adjacent to the spinous process and the cranial/medial to caudal/lateral } \\
\text { projection of its fibers. } L M \text { had isolated muscle bellies on the posterolateral region between } L 4 \text { and S1. }\end{array}$ \\
\hline
\end{tabular}

${ }_{1}^{1}=$ MRl; $2=$ USI; $3=\mathrm{CT} ; 4$ = Photo; 5 = Drawing; 6 = Modelling; 7 = Stereomicroscope; $8=$ Tractography.

${ }^{2} \mathrm{~L}=$ Location; $\mathrm{D}=$ Deep; $\mathrm{S}=$ Superficial

consensus meeting. There were no major differences between the descriptions and anatomical images of the LM in the literature with regard to the presence of images. The most difficult item to score was clear labeling.

The total quality scores of the studies varied between 1 and 5 (out of 5). The highest score [5/5] was found in $43 \%$ of the studies (129/303), with moderate scores [[2-4]/5] found in $39 \%$ of the studies (117/303) and low scores $[(\leq 2) / 5]$ found in $19 \%$ of the studies $(57 / 303)$. In the studies with quality scores of $5 / 5$ and $4 / 5$, MRI and USI were the most commonly used methods for visualizing the LM muscle (Fig. 3). More detailed data are presented in
Additional file 3. The majority of atlases were rated as being of moderate quality $[(3-4) / 5](79 \%, 15 / 19)$ or low quality $[(\leq 2) / 5](16 \%, 3 / 19)$. Only one atlas was found to be of high quality [5/5] (Table 5) [55].

\section{Discussion}

Substantial contradictory results were found across a large number of anatomy studies included in the review, and there appears to be no general consensus concerning the trajectory and muscle description of the LM [19, $23,25,29,35]$. Particularly with regard to the descriptions of "fiber trajectory" and "location", major

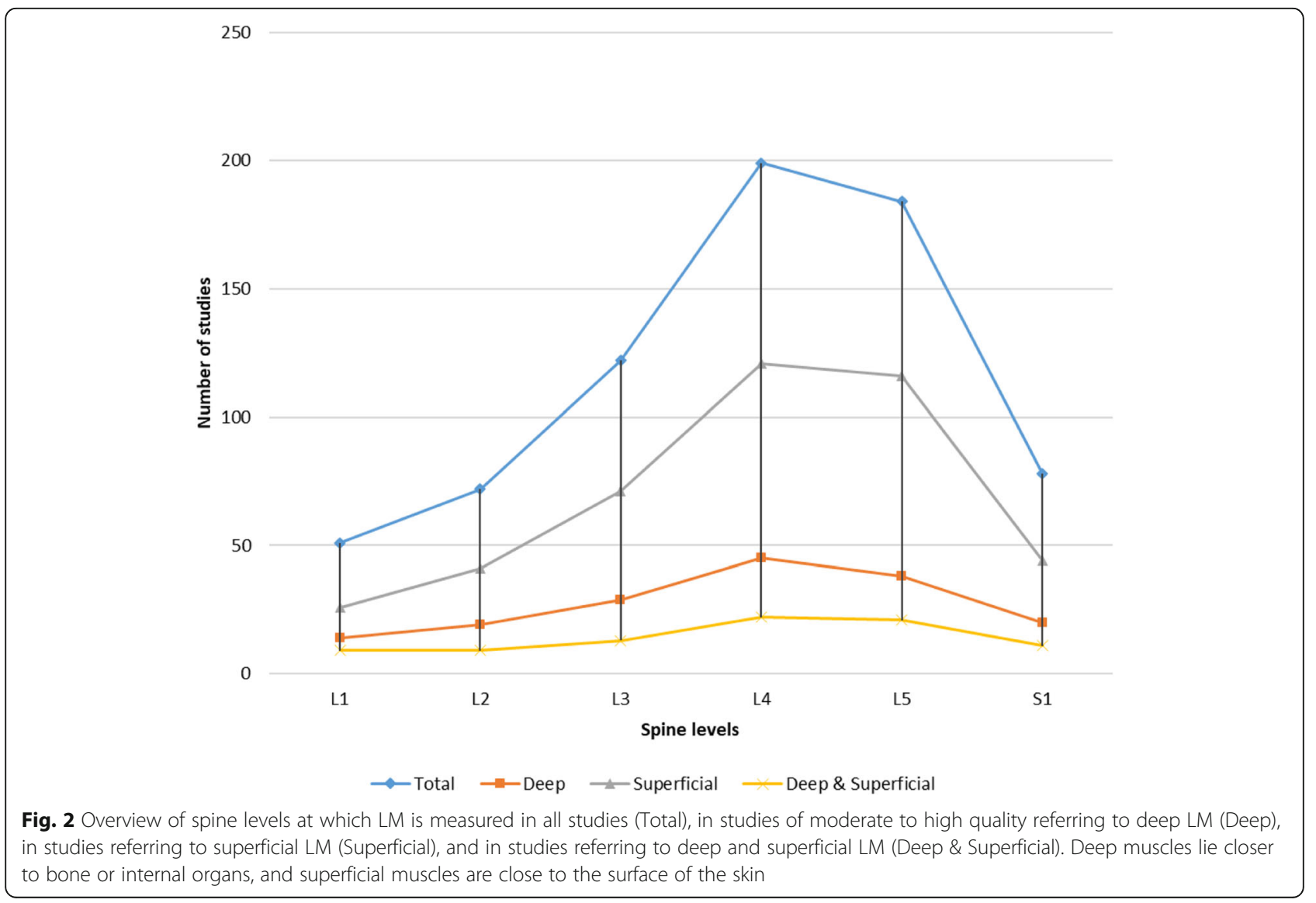


Table 3 Atlases describing the fiber trajectory of lumbar multifidus

\begin{tabular}{|c|c|c|c|c|c|}
\hline \multirow{2}{*}{$\begin{array}{l}\text { Author } \\
\text { year }\end{array}$} & \multirow[t]{2}{*}{ Method $^{2}$} & \multirow{2}{*}{$\begin{array}{l}\text { Spine } \\
\text { Level }\end{array}$} & \multirow[t]{2}{*}{$L^{1}$} & \multicolumn{2}{|l|}{ Fiber trajectory } \\
\hline & & & & Origin & Insertion \\
\hline $\begin{array}{l}\text { [56] A.M. } \\
\text { Gilroy } \\
2014\end{array}$ & 1 & C2-S5 & D & \multicolumn{2}{|c|}{ C2-sacrum: transverse and spinous processes with crossing to 2 to 4 vertebra } \\
\hline $\begin{array}{l}\text { [57] M. } \\
\text { Schuenke } \\
2010\end{array}$ & 1 & $\begin{array}{l}\text { C2- } \\
\text { sacrum }\end{array}$ & D & \multicolumn{2}{|c|}{$\begin{array}{l}\text { Courses between the transversus and spinous processes (2-4 vertebras) or all cervical vertebras most fully } \\
\text { developed in the lumbar spine. }\end{array}$} \\
\hline $\begin{array}{l}\text { [58] K.L. } \\
\text { Moore } \\
2010\end{array}$ & 1 & $\begin{array}{l}\text { C4 - } \\
\text { sacrum }\end{array}$ & D & \multicolumn{2}{|c|}{$\begin{array}{l}\text { Origin: LM arises from the posterior sacrum, PSIS of the ilium, aponeurosis of erector spinae, sacroiliac ligaments } \\
\text { mammillary processes of lumbar vertebras, transverse processes of T1-T3, articular processes of C4-C7 distal attach- } \\
\text { ment: thickest in the lumbar region. fibers pass obliquely super medially to the entire length of spinous processes, } \\
\text { located 2-4 segments, superior to the proximal attachment. }\end{array}$} \\
\hline $\begin{array}{l}{[60] \text { K.L. }} \\
\text { Moore } \\
2011\end{array}$ & 1 & $\begin{array}{l}\text { C4- } \\
\text { sacrum }\end{array}$ & D & $\begin{array}{l}\text { LM origin: arises from the posterior sacrum, PSIS of the } \\
\text { ilium, aponeurosis of erector spinae, sacroiliac } \\
\text { ligaments, mammillary processes of lumbar vertebras, } \\
\text { transverse processes of T1-T3 and articular processes of } \\
\text { C4-C7 }\end{array}$ & $\begin{array}{l}\text { LM insertion: Thickest in the lumbar region, fibers pass } \\
\text { obliquely superomedially to the entire length of } \\
\text { spinous processes of vertebras located } 2-4 \text { segments } \\
\text { superior to the origin. }\end{array}$ \\
\hline $\begin{array}{l}{[70] \text { W. }} \\
\text { Dauber } \\
2006\end{array}$ & 1 & $\begin{array}{l}\text { C1- } \\
\text { sacrum }\end{array}$ & D & $\begin{array}{l}\text { LM: sacrum, processes mammillary of vertebras. } \\
\text { Thoracic multifidus: transverse processes. Cervical } \\
\text { multifidus: caudal processes of cervical vertebras. }\end{array}$ & $\begin{array}{l}\text { LM: spinous processes L5-L1. Thoracic multifidus: spin- } \\
\text { ous processes T12-T1. Cervical multifidus: spinous pro- } \\
\text { cesses C7-C2. }\end{array}$ \\
\hline $\begin{array}{l}\text { [65] R.L. } \\
\text { Drake } \\
2010\end{array}$ & 1 & $\begin{array}{l}\text { T1- } \\
\text { sacrum }\end{array}$ & D & $\begin{array}{l}\text { Sacrum, the origin of erector spinae, PSIS, mammillary } \\
\text { processes of lumbar vertebras, transverse processes of } \\
\text { thoracic vertebras, and articular processes of lower four } \\
\text { cervical vertebras }\end{array}$ & $\begin{array}{l}\text { The base of spinous processes of all vertebras from } L 5 \\
\text { to } C 2 \text { (axis) }\end{array}$ \\
\hline $\begin{array}{l}{[61] \text { S. }} \\
\text { Standring } \\
2008\end{array}$ & 1 & $\begin{array}{l}\text { C2- } \\
\text { sacrum }\end{array}$ & D & \multicolumn{2}{|c|}{$\begin{array}{l}\text { At each segmental level multifidus is formed by several fascicles that arise from the caudal side of the lateral } \\
\text { surface of the spinous process and from the caudal side of its tip. They radiate caudally to insert into the } \\
\text { transverse elements of vertebrae two, three, four and five levels below (Machintosh et al. 1986). These sites are } \\
\text { represented at lumbar levels by the mammillary processes. Fascicles that extend beyond the fifth lumbar vertebra } \\
\text { insert into the dorsal surface of the sacrum. The longest fascicles from the first and second lumbar vertebras } \\
\text { insert into the dorsal segment of the iliac cest. From each spinous process, the shortest fascicles pass inferiorly } \\
\text { and laterally to their insertion; the longer fascicles assume a progressively steeper course and are arranged } \\
\text { progressively more medially. These fascicles from a given segment are flanked and overlapped dorsolateral by } \\
\text { fascicles from successively higher segments, an arrangement that endows the intact muscle with a laminated } \\
\text { structure. }\end{array}$} \\
\hline $\begin{array}{l}\text { [25] M. } \\
\text { Schunke } \\
2010\end{array}$ & 1 & $\begin{array}{l}\text { C2- } \\
\text { sacrum }\end{array}$ & D & \multicolumn{2}{|c|}{$\begin{array}{l}\text { Origin and insertion: multifidus run between transverses processes and spinous processes (across } 2 \text { to } 4 \text { vertebras) } \\
\text { of the whole spine (C2 to the sacrum). LM is strongest developed in the lumbar spine. }\end{array}$} \\
\hline $\begin{array}{l}{[67] \text { W. }} \\
\text { Platzer } \\
2012\end{array}$ & 1,2 & $\begin{array}{l}\text { C2- } \\
\text { sacrum }\end{array}$ & D & \multicolumn{2}{|c|}{$\begin{array}{l}\text { M. multifidus runs from the sacrum to C2. The muscle fibers arise separately from the superficial tendon of } \mathrm{m} \text {. } \\
\text { longissimus of the dorsal plan of sacrum, transverse processes of thoracic vertebras and the articular processes of } \\
\text { C2-C7. }\end{array}$} \\
\hline
\end{tabular}

${ }^{1}$ L=Location; $\mathrm{D}=$ Deep

21 = MRI; 2 = USI

differences were found between the studies by Macintosh and Bogduk (1986), Rosatelli et al. (2008), and Moseley et al. (2002), and those by Kim et al. (2015), Bojadsen et al. (2000), and De Foa et al. (1989) [1719, 29, 36, 40]. Discrepancies were also identified with regard to LM diameter, especially the distance

Table 4 Total scores for quality items, in numbers and percentages

\begin{tabular}{lll}
\hline$N(\%)$ & Studies $(n=303)$ & Atlases $(n=19)$ \\
Image present (yes) & $252(83 \%)$ & $19(100 \%)$ \\
Quality of images (sufficient) & $238(79 \%)$ & $6(32 \%)$ \\
Clear labeling (yes) & $200(66 \%)$ & $19(100 \%)$ \\
Presence of spine levels depicted (yes) & $236(78 \%)$ & $10(53 \%)$ \\
Description of plane (yes) & $232(77 \%)$ & $10(53 \%)$ \\
\hline
\end{tabular}

between the spinous process and the lateral margin of the LM at levels L4-S1 [46, 72] and its location relative to the ES $[46,72,73]$.

Each method that is used in literature to measure LM characteristics has its own strengths and limitations [30]. The architecture and function of the LM has been studied predominantly according to morphological and imaging methods. One disadvantage of cadaver studies [15, $17,22,29,36,40,46,74]$ is that the studies do not clearly identify the type and amount of structures (skin, fat, fascia, and muscle) that were removed from the cadaver. In these studies, it could be difficult to describe the exact location of the LM relative to other lumbar muscles and structures. The MRI and USI methods offer the advantage of being able to present undisturbed anatomy. This finding could have positive implications for 


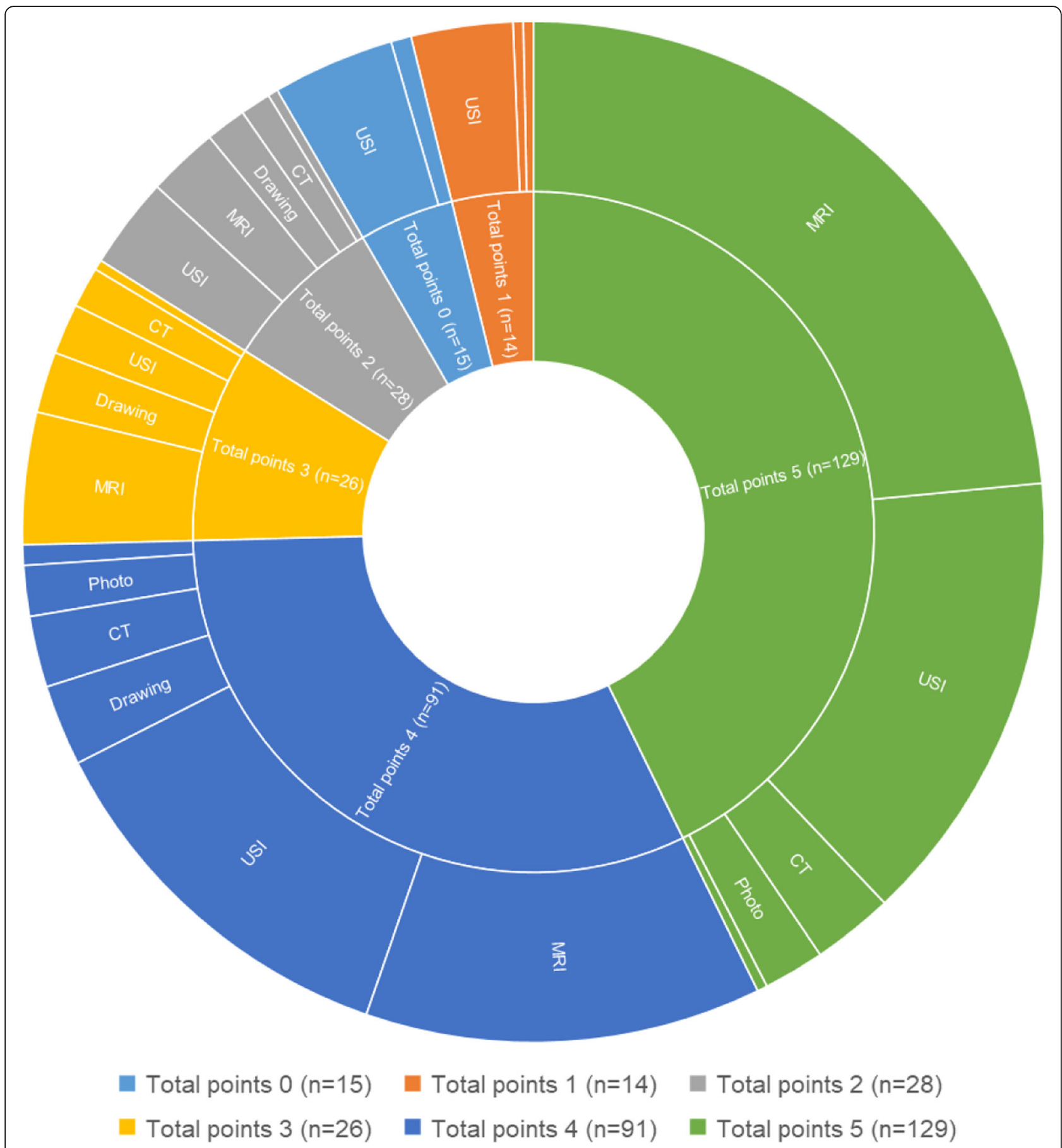

Fig. 3 Overview of the percentage of total scores on the quality-assessment tool (inside ring) and the associated percentage of techniques used (outside ring). Scores per study are presented in Additional file 3

clinical practice, given that USI is a user-friendly and affordable way to measure LM morphology in physiotherapy practice.

In anatomy atlases, the LM was depicted primarily as a relatively small deep muscle, in contrast to some research studies that refer to its large size and the presence of superficial slips at L4-S2 levels. Differences in LM images were identified even within anatomy atlases $[25,60,61,68]$. In Wolf-Heidegger's Atlas of Human Anatomy, LM insertion is depicted at the ventral side of the sacrum, in contrast to Gray's Anatomy, in which it is depicted at the dorsal side of the sacrum [61, 
Table 5 Data extraction of the atlases included $(n=19)$, sorted by quality score

\begin{tabular}{|c|c|c|c|c|}
\hline Author year & Method $^{2}$ & Spine Level & $\mathrm{L}^{1}$ & Quality $^{3}$ \\
\hline [55] L.G.F. Giles 1997 & 3,4 & L1-sacrum & $\mathrm{D}$ & 5 \\
\hline [56] A.M. Gilroy 2014 & 3 & $\mathrm{C2}-\mathrm{S} 5$ & D & 4 \\
\hline [57] M. Schuenke 2010 & 3 & C2-sacrum & $\mathrm{D}$ & 4 \\
\hline [58] K.L. Moore 2010 & 3 & C4 - sacrum & $D$ & 4 \\
\hline [59] J.W. Rohen 2011 & 4,2 & $L 1$ and L4 & D & 4 \\
\hline [60] K.L. Moore 2011 & 3 & C4-sacrum & $D$ & 4 \\
\hline [61] S. Standring 2008 & 3 & C2-sacrum & $\mathrm{D}$ & 4 \\
\hline [62] T.B. Moeller 2007 & 3,2 & L5 & D & 4 \\
\hline [63] R. Livingston 2011 & 1 & Abdomen, Pelvis & $\mathrm{D}$ & 4 \\
\hline [64] P.H. Abrahams 2013 & 4 & T12-sacrum & D & 3 \\
\hline [65] R.L. Drake 2010 & 3 & T1-sacrum & D & 3 \\
\hline [25] M. Schunke 2010 & 3 & C2-sacrum & D & 3 \\
\hline [66] G.Y. El-khoury 2007 & 1,2 & T10-sacrum & D & 3 \\
\hline [67] W. Platzer 2012 & 3,5 & C2-sacrum & D & 3 \\
\hline [24] F. Paulsen 2011 & 3 & C2-sacrum & D & 3 \\
\hline [68] P. Kopf-Maier 2000 & 3 & C2-sacrum & D & 3 \\
\hline [69] P.W. Tank 2009 & 3 & T1-sacrum & D & 2 \\
\hline [70] W. Dauber 2006 & 3 & C1-sacrum & $\mathrm{D}$ & 2 \\
\hline [71] H.J. van Donkelaar 2007 & 3,5 & C2-sacrum & $\mathrm{D}$ & 2 \\
\hline
\end{tabular}

${ }^{1}$ L=Location; $\mathrm{D}=$ Deep

$21=$ MRl; $2=$ USI; $3=\mathrm{CT} ; 4=$ Photo; 5 = Drawing

${ }^{3} 5=$ high quality; 4 or $3=$ moderate quality; $\leq 2$ = low quality

68]. Furthermore, in some atlases, the diameter and location of the LM is undefined, due to the overlying low back muscles [24, 67]. Overall, anatomy atlases reflect no consensus about the fiber trajectory of the LM, thus making it difficult for therapists, clinicians, and students to know and learn what is correct about LM morphology.

The inconsistencies in the descriptions and imaging of LM morphology in studies and atlases could be due to the differences in many parameters. Some of these variables are related to methodology (Fig. 2), spine levels, and/or type of population [26, 36, 75, 76]. Of particular note are the variations we found between LM images in anatomy atlases and those in studies. In some large studies $[15,26,77,78]$, the location and presentation of the LM differ from those in the most recent anatomy atlases $[24,25,55]$. One consistent finding in the anatomy atlases was that they all depict the LM as a deep lumbar muscle, whereas most studies presented it as a superficial lumbar muscle at the levels of L4-S1. We nevertheless identified some consistency in studies based on a USI LM protocol that had been developed in an earlier study (e.g., by Belavy et al.) [79-81]. The same protocol, which referred to similar images, has been used in different studies based on different research questions to present new knowledge about LM morphology.

\section{Limitations}

One possible limitation of this study could be that it might have overlooked some anatomy atlases, due to the lack of a database of anatomy atlases. Another limitation could be related to the reliability and validity of the quality-assessment tool that was developed and used by three authors of the current study. This qualityassessment tool was developed for lack of an existing "risk-of-bias assessment tool" with which to assess the quality of descriptions of LM morphology. It would be advisable to improve this assessment tool by conducting a validation and/or reliability study, as well as by expanding the tool beyond the current five items [34]. Any validation study regarding this quality-assessment tool will nevertheless be hampered by the current lack of a gold standard.

Variations in the images and measurement of LM morphology could be influenced by a number of potentially confounding factors, including research methods, level, side of measurement, population, intra-individual differences, intervention, research objectives, measurement technique (e.g., with or without contraction), and the relative experience of the assessors and/or practitioners creating the images. The variation that we observed in LM morphology emphasizes the importance of correct reference to morphology, although no gold standard for LM morphology has been developed to date. To reduce some of the existing variation, the authors call for improvement in the standardization of research protocols (e.g., in studies using EMG, USI, or MRI). The proper measurement of LM function could allow measurement of the contribution of the LM to spine movements in patients with non-specific LBP or other conditions. This knowledge could help clinicians and therapists to improve their diagnosis of patients.

\section{Clinical implications}

Remarkable differences in the reporting of LM morphology were found within anatomical studies, as well as between anatomical studies and anatomy atlases, especially with regard to trajectories of the musculature and its location relative to the ES. Such differences in the reporting of LM could have implications for clinical practice, given that knowledge of morphology provides the foundation for the diagnosis and treatment of patients by physiotherapists. For example, if the topography of a low back muscle (in terms of origin, insertion, deep/superficial) is clear, it should provide a clearer indication of the function of this low back muscle. This could make it easier to identify a cause or diagnosis of 
low back function or muscle impairment. For therapists or clinicians, these inconsistencies make it difficult to conclude which results are correct. Once therapists or clinicians know the correct LM morphology, this will clarify the function of the LM. Such knowledge could enhance understanding concerning the role of the LM in patients with LBP. It could also enhance the quality and consistency of decision-making by specialists concerning treatments for patients with LBP. Although a recent review on the effects of stabilizing therapy compared to usual care identified significant benefits of stabilizing therapy on pain and disability, these differences were not interpreted as clinically important [82]. Improved diagnosis may allow better sub-grouping, possibly enhancing the therapeutic effects for patients with LBP.

\section{Conclusion}

We identified a lack of standardization in the depiction and description of LM morphology, which may affect the precise understanding of its role in the background and therapy for patients with LBP. Standardization of research methodology with regard to LM morphology is recommended. Anatomy atlases should be updated on LM morphology.

\section{Supplementary information}

Supplementary information accompanies this paper at https://doi.org/10. 1186/s12891-020-03257-7.

Additional file 1. Search string

Additional file 2. Included anatomy atlases.

Additional file 3. Data extraction of all included studies

Additional file 4. Studies that measured thickness of lumbar multifidus.

Additional file 5. Legend of Additional files 3 and 4

\section{Abbreviations}

CSA: Cross-sectional area; ES: Erector spinae; LM: Lumbar multifidus;

PSIS: Posterior superior iliac spine; USI: Ultrasound imaging

\section{Acknowledgments}

Not applicable

\section{Authors' contributions}

AH developed the research strategy, included, reviewed and analyzed the studies and anatomy atlases and prepared the draft of the work. RS reviewed and analyzed the studies and anatomy atlases and was a major contributor in the writing of the manuscript. GG was a major contributor to the writing of the manuscript. HH, HW, FO, and AP substantively revised the work. In addition, all authors read and approved the final manuscript.

\section{Funding}

Nationaal Regieorgaan Praktijkgericht Onderzoek SIA. SIA had no role in the design of the study, in the collection, analysis, and interpretation of data or in the writing of the manuscript. This funding allowed the first author (AH) to work full-time on this manuscript.

Availability of data and materials Not applicable.
Ethics approval and consent to participate

Not applicable.

Consent for publication

Not applicable.

\section{Competing interests}

The authors declare that they have no competing interests.

\section{Author details}

${ }^{1}$ Anesthesiology Pain Center, University of Groningen, University Medical Center Groningen, Location Beatrixoord, Dilgtweg 5, Haren, the Netherlands. ${ }^{2}$ Faculty of Physical Activity and Health, Saxion University of Applied Sciences, Enschede, the Netherlands. ${ }^{3}$ Department of Biomedical Signals \& Systems, Faculty of Electrical Engineering, Mathematics and Computer Science, University of Twente, Enschede, the Netherlands. ${ }^{4} T e l e m e d i c i n e$ Group, Roessingh Research and Development, Enschede, the Netherlands. ${ }^{5}$ Department of Movement Science, Institute of Sport and Exercise Sciences, Münster, Germany.

Received: 31 October 2019 Accepted: 31 March 2020

Published online: 19 May 2020

\section{References}

1. Ko KJ, Ha GC, Yook YS, Kang SJ. Effects of 12-week lumbar stabilization exercise and sling exercise on lumbosacral region angle, lumbar muscle strength, and pain scale of patients with chronic low back pain. J Phys Ther Sci. 2018;30(1):18-22.

2. Bagheri R, Takamjani IE, Dadgoo M, Sarrafzadeh J, Ahmadi A, Pourahmadi $M R$, et al. A protocol for clinical trial study of the effect of core stabilization exercises on spine kinematics during gait with and without load in patients with non-specific chronic low back pain. Chiropr Man Ther. 2017:25:31.

3. Sung PS, Yoon B, Lee DC. Lumbar spine stability for subjects with and without low back pain during one-leg standing test. Spine. 2010;35(16): E753-60.

4. Wirth K, Hartmann H, Mickel C, Szilvas E, Keiner M, Sander A. Core stability in athletes: a critical analysis of current guidelines. Sports Med. 2017;47(3): 401-14

5. Hicks GE, Fritz JM, Delitto A, McGill SM. Preliminary development of a clinical prediction rule for determining which patients with low back pain will respond to a stabilization exercise program. Arch Phys Med Rehabil. 2005;86(9):1753-62.

6. Macedo LG, Latimer J, Maher CG, Hodges PW, McAuley JH, Nicholas MK, et al. Effect of motor control exercises versus graded activity in patients with chronic nonspecific low back pain: a randomized controlled trial. Physical Ther. 2012;92(3):363-77.

7. Fritz JM, Delitto A, Erhard R. Comparison of classification-based physical therapy with therapy based on clinical practice guidelines for patients with acute low back pain: a randomized clinical trial. Spine. 2003;28(13):1363-71.

8. Solomonow M, Zhou BH, Harris M, Lu Y, Baratta RV. The ligamento-muscular stabilizing system of the spine. Spine. 1998:23(23):2552-62.

9. Wilke HJ, Wolf $\mathrm{S}$, Claes LE, Arand M, Wiesend A. Stability increase of the lumbar spine with different muscle groups. A biomechanical in vitro study. Spine. 1995;20(2):192-8.

10. Wagner $H$, Anders C, Puta C, Petrovitch A, Mörl F, Schilling N, et al. Musculoskeletal support of lumbar spine stability. Pathophysiology. 2005; 12(4):257-65.

11. Hay EM, Dunn KM, Hill JC, Lewis M, Mason EE, Konstantinou K, et al. A randomised clinical trial of subgrouping and targeted treatment for low back pain compared with best current care. The STarT Back Trial Study Protocol. BMC Musculoskelet Disord. 2008;9:58

12. Hill JC, Dunn KM, Main CJ, Hay EM. Subgrouping low back pain: a comparison of the STarT Back Tool with the Orebro Musculoskeletal Pain Screening Questionnaire. Eur J Pain. 2010;14(1):83-9.

13. Hill JC, Whitehurst DG, Lewis M, Bryan S, Dunn KM, Foster NE, et al. Comparison of stratified primary care management for low back pain with current best practice (STarT Back): a randomised controlled trial. Lancet. 2011;378(9802):1560-71.

14. Stanton TR, Hancock MJ, Apeldoorn AT, Wand BM, Fritz JM. What characterizes people who have an unclear classification using a treatment- 
based classification algorithm for low back pain? A cross-sectional study. Phys Ther. 2013:93(3):345-55.

15. Deng $X$, Zhu $Y$, Wang $S$, Zhang $Y$, Han $H$, Zheng $D$, et al. $C T$ and MRI determination of intermuscular space within lumbar paraspinal muscles at different intervertebral disc levels. PLoS One. 2015;10(10).

16. Fortin M, Macedo LG. Multifidus and paraspinal muscle group crosssectional areas of patients with low back pain and control patients: a systematic review with a focus on blinding. Phys Ther. 2013;93(7):873-88.

17. Macintosh JE, Valencia F, Bogduk N, Munro RR. The morphology of the human lumbar multifidus. Clin Biomech. 1986;1(4):196-204.

18. Kim YE, Choi HW. Effect of disc degeneration on the muscle recruitment pattern in upright posture: a computational analysis. Comput Methods Biomech Biomed Eng. 2015;18(15):1622-31.

19. Moseley GL, Hodges PW, Gandevia SC. Deep and superficial fibers of the lumbar multifidus muscle are differentially active during voluntary arm movements. Spine. 2002;27(2):E29-36.

20. Battie MC, Niemelainen R, Gibbons LE, Dhillon S. Is level- and side-specific multifidus asymmetry a marker for lumbar disc pathology? Spine J. 2012; 12(10):932-9.

21. Kjaer P, Bendix T, Sorensen JS, Korsholm L, Leboeuf-Yde C. Are MRI-defined fat infiltrations in the multifidus muscles associated with low back pain? BMC Med. 2007;5:2.

22. Ward SR, Kim CW, Eng CM, Gottschalk LJ, Tomiya A, Garfin SR, et al. Architectural analysis and intraoperative measurements demonstrate the unique design of the multifidus muscle for lumbar spine stability. J Bone Joint Surg Am. 2009;91(1):176-85.

23. Bogduk N. Clinical anatomy of the lumbar spine and sacrum. 3rd ed. New York: Churchill Livingstone; 1997.

24. Paulsen F, Waschke J. Sobotta 1 Algemene anatomie en bewegingsapparaat: Atlas van de menselijke anatomie: Bohn Stafleu van Loghum; 2011.

25. Schünke M, Schulte E, Schumacher U, Voll M, Wesker K, MediLingua. Prometheus: anatomische atlas / Algemene anatomie en bewegingsapparaat / [vert. uit het Duits: MediLingua]. 2nd ed. Houten: Bohn Stafleu van Loghum; 2010.

26. Beneck GJ, Kulig K. Multifidus atrophy is localized and bilateral in active persons with chronic unilateral low back pain. Arch Phys Med Rehabil. 2012; 93(2):300-6.

27. Zhao WP, Kawaguchi Y, Matsui H, Kanamori M, Kimura T. Histochemistry and morphology of the multifidus muscle in lumbar disc herniation: Comparative study between diseased and normal sides. Spine. 2000;25(17):2191-9.

28. Bajek S, Bobinac D, Bajek G, Vranic TS, Lah B, Dragojevic DM. Muscle fiber type distribution in multifidus muscle in cases of lumbar disc herniation. Acta Med Okayama. 2000;54(6):235-41.

29. Rosatelli AL, Ravichandiran K, Agur AM. Three-dimensional study of the musculotendinous architecture of lumbar multifidus and its functional implications. Clin Anat. 2008;21(6):539-46.

30. Gibbons LE, Latikka P, Videman T, Manninen H, Battié MC. The association of trunk muscle cross-sectional area and magnetic resonance image parameters with isokinetic and psychophysical lifting strength and static back muscle endurance in men. J Spinal Disord. 1997:10(5):398-403.

31. Arksey H, O'Malley L. Scoping studies: towards a methodological framework. Int J Soc Res Methodol. 2005;8(1):19-32.

32. Grudniewicz A, Nelson M, Kuluski K, Lui V, Cunningham HV, Nie XJ, et al. Treatment goal setting for complex patients: protocol for a scoping review. BMJ Open. 2016;6(5):e011869.

33. Kim SY, Park JE, Lee YJ, Seo HJ, Sheen SS, Hahn S, et al. Testing a tool for assessing the risk of bias for nonrandomized studies showed moderate reliability and promising validity. J Clin Epidemiol. 2013;66(4):408-14.

34. Henry BM, Tomaszewski KA, Ramakrishnan PK, Roy J, Vikse J, Loukas M, et al. Development of the Anatomical Quality Assessment (AQUA) Tool for the quality assessment of anatomical studies included in meta-analyses and systematic reviews. Clin Anat. 2017;30(1):6-13.

35. Bogduk N, Macintosh JE, Pearcy MJ. A universal model of the lumbar back muscles in the upright position. Spine. 1992;17(8):897-913.

36. Bojadsen TWA, Silva ES, Rodrigues AJ, Amadio AC. Comparative study of Mm. Multifidi in lumbar and thoracic spine. J Electromyogr Kinesiol. 2000; 10(3):143-9.

37. Creze M, Nyangoh Timoh K, Gagey O, Rocher L, Bellin MF, Soubeyrand M. Feasibility assessment of shear wave elastography to lumbar back muscles: A Radioanatomic Study. Clin Anat. 2017;30(6):774-80.
38. Creze M, Soubeyrand M, Nyangoh Timoh K, Gagey O. Organization of the fascia and aponeurosis in the lumbar paraspinal compartment. Surg Radio Anat. 2018;40(11):1231-42.

39. Creze M, Soubeyrand M, Gagey O. The paraspinal muscle-tendon system: Its paradoxical anatomy. PLoS One. 2019;14(4):e0214812.

40. De Foa JL, Forrest W, Biedermann HJ. Muscle fibre direction of longissimus, iliocostalis and multifidus: landmark-derived reference lines. J Anat. 1989; 163:243-7.

41. Jemmett RS, Macdonald DA, Agur AM. Anatomical relationships between selected segmental muscles of the lumbar spine in the context of multiplanar segmental motion: a preliminary investigation. Man Ther. 2004;9(4): 203-10.

42. Kader DF, Wardlaw D, Smith FW. Correlation between the MRI changes in the lumbar multifidus muscles and leg pain. Clin Radiol. 2000;55(2):145-9.

43. Kramer M, Katzmaier P, Eisele R, Ebert V, Kinzl L, Hartwig E. Surface electromyography-verified muscular damage associated with the open dorsal approach to the lumbar spine. Eur Spine J. 2001;10(5):414-20.

44. Macintosh JE, Bogduk N. The biomechanics of the lumbar multifidus. Clin Biomech. 1986;1 (4):205-13.

45. Lonnemann ME, Paris SV, Gorniak GC. A morphological comparison of the human lumbar multifidus by chemical dissection. J Man Manipulative Ther. 2008;16(4):E84-92

46. Vialle R, Court C, Khouri N, Olivier E, Miladi L, Tassin JL, et al. Anatomical study of the paraspinal approach to the lumbar spine. Eur Spine J. 2005; 14(4):366-71.

47. Hides J, Gilmore C, Stanton W, Bohlscheid E. Multifidus size and symmetry among chronic LBP and healthy asymptomatic subjects. Man Ther. 2008; 13(1):43-9.

48. Djordjevic O, Konstantinovic L, Miljkovic N, Bijelic G. Relationship between electromyographic signal amplitude and thickness change of the trunk muscles in patients with and without low back pain. Clin J Pain. 2015;31(10): 893-902.

49. Fortin M, Gibbons LE, Videman T, Battie MC. Do variations in paraspinal muscle morphology and composition predict low back pain in men? Scand J Med Sci Sports. 2015;25(6):880-7.

50. Zapata KA, Wang-Price S, Sucato DJ, Dempsey-Robertson M. Ultrasonographic measurements of paraspinal muscle thickness in adolescent idiopathic scoliosis: a comparison and reliability study. Pediatr Phys Ther. 2015;27(2):119-25.

51. Le Cara EC, Marcus RL, Dempsey AR, Hoffman MD, Hebert JJ. Morphology versus function: The relationship between lumbar multifidus intramuscular adipose tissue and muscle function among patients with low back pain. Arch Phys Med Rehabil. 2014;95(10):1846-52.

52. Sions JM, Velasco TO, Teyhen DS, Hicks GE. Ultrasound imaging: intraexaminer and interexaminer reliability for multifidus muscle thickness assessment in adults aged 60 to 85 years versus younger adults. J Orthop Sports Phys Ther. 2014;44(6):425-34.

53. Cho M. The effects of modified wall squat exercises on average adults' deep abdominal muscle thickness and lumbar stability. J Phys Ther Sci. 2013;25(6): 689-92.

54. Lariviere C, Gagnon D, De Oliveira E Jr, Henry SM, Mecheri H, Dumas JP. Ultrasound measures of the lumbar multifidus: effect of task and transducer position on reliability. PM R. 2013;5(8):678-87.

55. Giles LGF, Singer KP. Clinical anatomy and management of low back pain. Oxford: Butterworth Heinemann; 1997.

56. Gilroy AM, Schünke M, Voll M, Braches K. Anatomische Atlas. Tweede editie. ed. Houten: Bohn Stafleu van Loghum, Springer Media; 2014.

57. Schünke M, Schulte E, Schumacher U, Rude J Jr, Ross LM, Lamperti ED, et al. Thieme atlas of anatomy / [Vol. 1], General anatomy and musculoskeletal system. [Corr. reprint]. ed. Stuttgart: Thieme; 2010.

58. Moore KL, Dalley AF II, Agur AMR. Clinically oriented anatomy. 6th ed. Philadelphia: Wolters Kluwer Health/Lippincott Williams \& Wilkins; 2010.

59. Rohen JW, Yokochi C, Lütjen-Drecoll E. Color atlas of anatomy: a photographic study of the human body. 7th ed. Philadelphia: Wolters Kluwer/Lippincott Williams \& Wilkins; 2011.

60. Moore KL, Agur AMR, Dalley AF. Essential clinical anatomy. 4th ed. Baltimore: Lippincott Williams \& Wilkins; 2011. p. 703.

61. Standring S, Gray H. Gray's anatomy : the anatomical basis of clinical practice. 40th ed. Edinburgh: Churchill Livingstone/Elsevier; 2008.

62. Torsten BM, Emil R. Book: Pocket atlas of sectional anatomy, pocket atlas of sectional anatomy. Neuroradiol J. 2007;20(3):383-4. 
63. Livingston R. Radiology anatomy atlas viewer: Bearboat SP; 2011.

64. Abrahams PH. McMinn and Abrahams' clinical atlas of human anatomy. 7th ed. Edinburgh: Mosby; 2013.

65. Drake RL, Vogl W, Mitchell AWM, Gray H. Gray's anatomy for students. 2nd ed. Philadelphia: Churchill Livingstone/Elsevier; 2010.

66. Khoury GY, Montgomery WJ. Sectional anatomy by MRI and CT. 3rd ed. Edinburgh: Churchill Livingstone Elsevier; 2007.

67. Platzer W, Spitzer G, en Burger S. Sesam Atlas van de anatomie / DI. 1, Bewegingsapparaat / door Werner Platzer ; ill. Gerhard Spitzer ; [m.m.v. Stefanie Gay ... et al. ; vert. uit het Duits: Burger \& Schwarz]. 22e, geheel herz. dr. ed. Amersfoort: ThiemeMeulenhoff; 2012.

68. Wolf-Heidegger G, Köpf-Maier P. Wolf-Heidegger's atlas of human anatomy. 5th, completely rev. and supplemented ed. / ed. Basel: Karger; 2000.

69. Tank PW, Gest TR, Burkel WE, Lippincott W. Wilkins. Lippincott Williams \& Wilkins atlas of anatomy. Philadelphia: Wolters Kluwer Health/Lippincott Williams \& Wilkins; 2009

70. Dauber W, Feneis $\mathrm{H}$, Gribnau AAM. Feneis' geill ustreerd anatomisch zakwoordenboek. 4th ed. Houten: Bohn Stafleu Van Loghum; 2006.

71. Donkelaar HJ, Lohman AHM. Klinische anatomie en embryologie / DI. 2. 3rd ed. Maarssen: Elsevier gezondheidszorg; 2007.

72. Palmer DK, Allen JL, Williams PA, Voss AE, Jadhav V, Wu DS, et al. Multilevel magnetic resonance imaging analysis of multifidus-longissimus cleavage planes in the lumbar spine and potential clinical applications to Wiltse's paraspinal approach. Spine. 2011;36(16):1263-7.

73. Li H, Yang L, Chen J, Xie H, Tian W, Cao X. Magnetic resonance imagingbased anatomical study of the multifidus-longissimus cleavage planes in the lumbar spine. Am J Transl Res. 2016;8(1):109-16.

74. Rantanen J, Rissanen A, Kalimo H. Lumbar muscle fiber size and type distribution in normal subjects. Eur Spine J. 1994;3(6):331-5.

75. Koppenhaver SL, Hebert JJ, Fritz JM, Parent EC, Teyhen DS, Magel JS Reliability of Rehabilitative Ultrasound Imaging of the Transversus Abdominis and Lumbar Multifidus Muscles. Arch Phys Med Rehabil. 2009; 90(1):87-94

76. Kiesel KB, Underwood FB, Matacolla C, Nitz AJ, Malone TR. A comparison of select trunk muscle thickness change between subjects with low back pain classified in the treatment-based classification system and asymptomatic controls. J Orthop Sports Phys Ther. 2007;37(10):596-607.

77. Kim WH, Lee SH, Lee DY. Changes in the cross-sectional area of multifdus and psoas in unilateral sciatica caused by lumbar disc herniation. J Korean Neurosurg Soc. 2011;50(3):201-4.

78. Yoo JS, Min SH, Yoon SH, Hwang CH. Paraspinal muscle changes of unilateral multilevel minimally invasive transforaminal interbody fusion. J Orthop Surg Res. 2014;9:130.

79. Belavy DL, Bansmann PM, Bohme G, Frings-Meuthen P, Heer M, Rittweger J, et al. Changes in intervertebral disc morphology persist 5 mo after 21-day bed rest. J Appl Physiol. 2011;111(5):1304-14.

80. Belavy DL, Armbrecht G, Felsenberg D. Real-time ultrasound measures of lumbar erector spinae and multifidus: reliability and comparison to magnetic resonance imaging. Physiol Meas. 2015;36(11):2285-99.

81. Belavy DL, Gast U, Felsenberg D. Exercise and Transversus Abdominis Muscle Atrophy after 60-d Bed Rest. Med Sci Sports Exerc. 2017:49(2):238-46.

82. Smith BE, Littlewood C, May S. An update of stabilisation exercises for low back pain: a systematic review with meta-analysis. BMC Musculoskelet Disord. 2014;15:416.

83. Abbas J, Slon V, May H, Peled N, Hershkovitz I, Hamoud K. Paraspina muscles density: a marker for degenerative lumbar spinal stenosis? BMC Musculoskelet Disord. 2016;17(1):422.

84. Altinkaya N, Cekinmez M. Lumbar multifidus muscle changes in unilateral lumbar disc herniation using magnetic resonance imaging. Skelet Radiol. 2016;45(1):73-7.

85. Annaswamy TM, Bierner SM, Doppalapudi H. Does lumbar dorsal ramus syndrome have an objective clinical basis? PM R. 2013:5(12):996-1006.

86. Bang WS, Lee DH, Kim KT, Cho DC, Sung JK, Han IB, et al. Relationships between vitamin $\mathrm{D}$ and paraspinal muscle: human data and experimental rat model analysis. Spine J. 2018;18(6):1053-61

87. Banno T, Yamato Y, Hasegawa T, Kobayashi S, Togawa D, Oe S, et al. Assessment of the cross-sectional areas of the psoas major and multifidus muscles in patients with adult spinal deformity. Clin Spine Surg. 2017;30(7):E968-E73.

88. Berry DB, Padwal J, Johnson S, Parra CL, Ward SR, Shahidi B. Methodological considerations in region of interest definitions for paraspinal muscles in axial MRIs of the lumbar spine. BMC Musculoskelet Disord. 2018;19(1):135.
89. Bresnahan LE, Smith JS, Ogden AT, Quinn S, Cybulski GR, Simonian N, et al. Assessment of paraspinal muscle cross-sectional area after lumbar decompression. Clin Spine Surg. 2017;30(3):E162-E8.

90. Cawley DT, Alexander M, Morris S. Multifidus innervation and muscle assessment post-spinal surgery. Eur Spine J. 2014;23(2):320-7.

91. Chang DG, Healey RM, Snyder AJ, Sayson JV, Macias BR, Coughlin DG, et al. Lumbar spine paraspinal muscle and intervertebral disc height changes in astronauts after long-duration spaceflight on the international space station. Spine. 2016;41(24):1917-24.

92. Chatani K. A novel surgical approach to the lumbar spine involving hemilateral split-off of the spinous process to preserve the multifidus muscle: technical note. J Neurosurg Spine. 2016;24(5):694-9.

93. Chon J, Kim HS, Lee JH, Yoo SD, Yun DH, Kim DH, et al. Asymmetric atrophy of paraspinal muscles in patients with chronic unilateral lumbar radiculopathy. Ann Rehabil Med. 2017;41(5):801-7.

94. Clark BC, Walkowski S, Conatser RR, Eland DC, Howell JN. Muscle functional magnetic resonance imaging and acute low back pain: a pilot study to characterize lumbar muscle activity asymmetries and examine the effects of osteopathic manipulative treatment. Osteopath Med Prim Care. 2009;3:7.

95. Coldron Y, Stokes M, Cook K. Lumbar multifidus muscle size does not differ whether ultrasound imaging is performed in prone or side lying. Man Ther. 2003;8(3):161-5.

96. Creze M, Soubeyrand M, Yue JL, Gagey O, Maitre X, Bellin MF. Magnetic resonance elastography of the lumbar back muscles: A preliminary study. Clin Anat. 2018;31(4):514-20

97. Cuellar WA, Blizzard L, Callisaya ML, Hides JA, Jones G, Ding C, et al. Testretest reliability of measurements of abdominal and multifidus muscles using ultrasound imaging in adults aged 50-79 years. Musculoskelet Sci Pract. 2016;28:79-84.

98. Danneels LA, Vanderstraeten GG, Cambier DC, Witvrouw EE, Bourgois J, Dankaerts $W$, et al. Effects of three different training modalities on the cross sectional area of the lumbar multifidus muscle in patients with chronic low back pain. Br J Sports Med. 2001;35(3):186-91.

99. Deng $X$, Zhu Y, Wang S, Zhang Y, Han H, Zheng D, et al. CT and MRI determination of intermuscular space within lumbar paraspinal muscles at different intervertebral disc levels. PLoS One. 2015;10(10):e140315.

100. D'Hooge R, Cagnie B, Crombez G, Vanderstraeten G, Dolphens M, Danneels L. Increased intramuscular fatty infiltration without differences in lumbar muscle cross-sectional area during remission of unilateral recurrent low back pain. Man Ther. 2012;17(6):584-8.

101. D'Hooge R, Cagnie B, Crombez G, Vanderstraeten G, Achten E, Danneels L. Lumbar muscle dysfunction during remission of unilateral recurrent nonspecific low-back pain: evaluation with muscle functional MRI. Clin J Pain. 2013;29(3):187-94.

102. Dickx N, Cagnie B, Achten E, Vandemaele P, Parlevliet T, Danneels L. Differentiation between deep and superficial fibers of the lumbar multifidus by magnetic resonance imaging. Eur Spine J. 2010;19(1):122-8.

103. Dickx N, Cagnie B, Achten E, Vandemaele P, Parlevliet T, Danneels L. Changes in lumbar muscle activity because of induced muscle pain evaluated by muscle functional magnetic resonance imaging. Spine. 2008; 33(26):E983-9.

104. Dickx N, D'Hooge R, Cagnie B, Deschepper E, Verstraete K, Danneels L. Magnetic resonance imaging and electromyography to measure lumbar back muscle activity. Spine. 2010;35(17):E836-E42.

105. Fan $S$, Hu Z, Zhao F, Zhao X, Huang $Y$, Fang X. Multifidus muscle changes and clinical effects of one-level posterior lumbar interbody fusion: Minimally invasive procedure versus conventional open approach. Eur Spine J. 2010; 19(2):316-24.

106. Farshad M, Gerber C, Farshad-Amacker NA, Dietrich TJ, Laufer-Molnar V, Min K. Asymmetry of the multifidus muscle in lumbar radicular nerve compression. Skelet Radiol. 2014;43(1):49-53.

107. Gellhorn AC, Suri P, Rundell SD, Olafsen N, Carlson MJ, Johnson S, et al. Lumbar muscle cross-sectional areas do not predict clinical outcomes in adults with spinal stenosis: A longitudinal study. PM R. 2017:9(6):545-55.

108. Ghiasi MS, Arjmand N, Shirazi-Adl A, Farahmand F, Hashemi H, Bagheri S, et al. Cross-sectional area of human trunk paraspinal muscles before and after posterior lumbar surgery using magnetic resonance imaging. Eur Spine J. 2016;25(3):774-82.

109. Gibbon KC, Debuse D, Hibbs A, Caplan N. Reliability and precision of sonography of the lumbar multifidus and transversus abdominis during dynamic activities. J Ultrasound Med. 2017;36(3):571-81. 
110. Gildea JE, Hides JA, Hodges PW. Size and symmetry of trunk muscles in ballet dancers with and without low back pain. J Orthop Sports Phys Ther. 2013;43(8):525-33.

111. Hides JA, Cooper DH, Stokes MJ. Diagnostic ultrasound imaging for measurement of the lumbar multifidus muscle in normal young adults. Physiother Theory Pract. 1992:8(1):19-26.

112. Hides J, Stanton W, McMahon S, Sims K, Richardson C. Effect of stabilization training on multifidus muscle cross-sectional area among young elite cricketers with low back pain. J Orthop Sports Phys Ther. 2008;38(3):101-8.

113. Hides JA, Brown CT, Penfold L, Stanton WR. Screening the lumbopelvic muscles for a relationship to injury of the quadriceps, hamstrings, and adductor muscles among elite Australian Football League players. J Orthop Sports Phys Ther. 2011;41(10):767-75.

114. Hides JA, Stanton WR, Mendis MD, Franettovich Smith MM, Sexton MJ. Small multifidus muscle size predicts football injuries. Orthop J Sports Med. 2014;2(6).

115. Hides JA, Lambrecht G, Stanton WR, Damann V. Changes in multifidus and abdominal muscle size in response to microgravity: possible implications for low back pain research. Eur Spine J. 2016;25:175-82.

116. Hides JA, Oostenbroek T, Franettovich Smith MM, Mendis MD. The effect of low back pain on trunk muscle size/function and hip strength in elite football (soccer) players. J Sports Sci. 2016;34(24):2303-11.

117. Hides JA, Walsh JC, Smith MMF, Mendis MD. Self-managed exercises, fitness and strength training, and multifidus muscle size in elite footballers. J Athl Train. 2017;52(7):649-55.

118. Hiepe P, Gussew A, Rzanny R, Anders C, Walther M, Scholle HC, et al. Interrelations of muscle functional MRI, diffusion-weighted MRI and (31) PMRS in exercised lower back muscles. NMR Biomed. 2014;27(8):958-70.

119. Hiepe P, Gussew A, Rzanny R, Kurz E, Anders C, Walther M, et al. Age-related structural and functional changes of low back muscles. Exp Gerontol. 2015; 65:23-34.

120. Hyun JK, Lee JY, Lee SJ, Jeon JY. Asymmetric atrophy of multifidus muscle in patients with unilateral lumbosacral radiculopathy. Spine. 2007;32(21): E598-602.

121. Jiang J, Wang $H$, Wang L, Zhang B, Guo Q, Yuan W, et al. Multifidus degeneration, a new risk factor for lumbar spinal stenosis: A case-control study. World Neurosurg. 2017:99:226-31.

122. Johnson GM, Zhang M. Regional differences within the human supraspinous and interspinous ligaments: A sheet plastination study. Eur Spine J. 2002;11(4):382-8.

123. Kader D, Radha S, Banaszkiewicz PA, Stocker M, Dunbar-Smith L, Smith FW. Gym ball exercise leads to recruitment and increased water content of the paraspinal muscles: An MRI pilot study. J Back Musculoskelet Rehabil. 2008; 21(2):77-85.

124. Kamaz M, Kiresi D, Oguz H, Emlik D, Levendoglu F. CT measurement of trunk muscle areas in patients with chronic low back pain. Diagn Interv Radiol. 2007;13(3):144-8.

125. Kang CH, Shin MJ, Kim SM, Lee SH, Lee CS. MRI of paraspinal muscles in lumbar degenerative kyphosis patients and control patients with chronic low back pain. Clin Radiol. 2007;62(5):479-86.

126. Kang Jl, Kim SY, Kim JH, Bang H, Lee IS. The location of multifidus atrophy in patients with a single level, unilateral lumbar radiculopathy. Ann Rehabil Med. 2013;37(4):498-504

127. Katsu M, Ohba T, Ebata S, Haro H. Comparative study of the paraspinal muscles after OVF between the insufficient union and sufficient union using MRI. BMC Musculoskelet Disord. 2018:19(1):143.

128. Kiesel KB, Uhl TL, Underwood FB, Rodd DW, Nitz AJ. Measurement of lumbar multifidus muscle contraction with rehabilitative ultrasound imaging. Man Ther. 2007;12(2):161-6.

129. Kiesel KB, Uhl T, Underwood FB, Nitz AJ. Rehabilitative ultrasound measurement of select trunk muscle activation during induced pain. Man Ther. 2008;13(2):132-8

130. Koppenhaver SL, Fritz JM, Hebert JJ, Kawchuk GN, Parent EC, Gill NW, et al. Association between history and physical examination factors and change in lumbar multifidus muscle thickness after spinal manipulation in patients with low back pain. J Electromyogr Kinesiol. 2012;22(5):724-31.

131. Kulig K, Scheid AR, Beauregard R, Popovich JM Jr, Beneck GJ, Colletti PM. Multifidus morphology in persons scheduled for single-level lumbar microdiscectomy: Qualitative and quantitative assessment with anatomical correlates. Am J Phys Med Rehabil. 2009;88(5):355-61.

132. Lariviere C, Gagnon DH, Henry SM, Preuss R, Dumas JP. The effects of an 8week stabilization exercise program on lumbar multifidus muscle thickness and activation as measured with ultrasound imaging in patients with low back pain: An exploratory study. PM R. 2018;10(5):483-93.

133. Lee HI, Lee ST, Kim M, Ryu JS. Sex differences in predicting chronicity of low-back pain after acute trauma using lumbar muscle area. Am J Phys Med Rehabil Assoc Acad Phys. 2014;94(2):123-30.

134. Lee SH, Park SW, Kim YB, Nam TK, Lee YS. The fatty degeneration of lumbar paraspinal muscles on computed tomography scan according to age and disc level. Spine J. 2017;17(1):81-7.

135. Liu IS, Chai HM, Yang JL, Wang SF. Inter-session reliability of the measurement of the deep and superficial layer of lumbar multifidus in young asymptomatic people and patients with low back pain using ultrasonography. Manual Ther. 2013;18(6):481-6.

136. Macdonald DA, Dawson AP, Hodges PW. Behavior of the lumbar multifidus during lower extremity movements in people with recurrent low back pain during symptom remission. J Orthop Sports Phys Ther. 2011:41(3):155-64.

137. Masaki M, Ikezoe T, Fukumoto Y, Minami S, Tsukagoshi R, Sakuma K, et al. Association of sagittal spinal alignment with thickness and echo intensity of lumbar back muscles in middle-aged and elderly women. Arch Geronto Geriatr. 2015:61(2):197-201.

138. Masse-Alarie H, Beaulieu LD, Preuss R, Schneider C. Corticomotor control of lumbar multifidus muscles is impaired in chronic low back pain: concurrent evidence from ultrasound imaging and double-pulse transcranial magnetic stimulation. Exp Brain Res. 2016;234(4):1033-45.

139. Oh J, Jung JY, Ko YJ. Can diffusion tensor imaging and tractography represent cross-sectional area of lumbar multifidus in patients with LUMBAR spine disease? Muscle Nerve. 2018;57(2):200-5.

140. Paalanne N, Niinimaki J, Karppinen J, Taimela S, Mutanen P, Takatalo J, et al. Assessment of association between low back pain and paraspinal muscle atrophy using opposed-phase magnetic resonance imaging: a populationbased study among young adults. Spine. 2011;36(23):1961-8.

141. Pressler JF, Heiss DG, Buford JA, Chidley JV. Between-day repeatability and symmetry of multifidus cross-sectional area measured using ultrasound imaging. J Orthop Sports Phys Ther. 2006;36(1):10-8.

142. Ranson CA, Burnett AF, Kerslake R, Batt ME, O'Sullivan PB. An investigation into the use of MR imaging to determine the functional cross sectional area of lumbar paraspinal muscles. Eur Spine J. 2006;15(6):764-73.

143. Ranson C, Burnett A, O'Sullivan P, Batt M, Kerslake R. The lumbar paraspinal muscle morphometry of fast bowlers in cricket. Clin J Sport Med. 2008;18(1): $31-7$.

144. Sakai W, Nakane S, Urasaki E, Toyoda K, Sadakata E, Nagaishi A, et al. The cross-sectional area of paraspinal muscles predicts the efficacy of deep drain stimulation for camptocormia. J Park Dis. 2017;7(2):247-53.

145. Sions JM, Velasco TO, Teyhen DS, Hicks GE. Reliability of ultrasound imaging for the assessment of lumbar multifidi thickness in older adults with chronic low back pain. J Geriatr Phys Ther. 2015;38(1):33-9.

146. Sions JM, Teyhen DS, Hicks GE. Criterion validity of ultrasound imaging: assessment of multifidi cross-sectional area in older adults with and without chronic low back pain. J Geriatr Phys Ther. 2017;40(2):74-9

147. Sitilertpisan P, Hides J, Stanton W, Paungmali A, Pirunsan U. Multifidus muscle size and symmetry among elite weightlifters. Phys Ther Sport. 2012; 13(1):11-5.

148. Smuck M, Crisostomo RA, Demirjian R, Fitch DS, Kennedy DJ, Geisser ME. Morphologic changes in the lumbar spine after lumbar medial branch radiofrequency neurotomy: a quantitative radiological study. Spine J. 2015; 15(6):1415-21.

149. Stokes M, Rankin G, Newham DJ. Ultrasound imaging of lumbar multifidus muscle: normal reference ranges for measurements and practical guidance on the technique. Man Ther. 2005;10(2):116-26.

150. Storheim K, Berg L, Hellum C, Gjertsen Ã, Neckelmann G, Espeland A, et al. Fat in the lumbar multifidus muscles - predictive value and change following disc prosthesis surgery and multidisciplinary rehabilitation in patients with chronic low back pain and degenerative disc: 2-year follow-up of a randomized trial. BMC Musculoskelet Disord. 2017;18(1).

151. Suh DW, Kim Y, Lee M, Lee S, Park SJ, Yoon B. Reliability of histographic analysis for paraspinal muscle degeneration in patients with unilateral back pain using magnetic resonance imaging. J Back Musculoskelet Rehabilit. 2017;30(3):403-12

152. Sweeney N, O'Sullivan C, Kelly G. Multifidus muscle size and percentage thickness changes among patients with unilateral chronic low back pain (CLBP) and healthy controls in prone and standing. Man Ther. 2014;19(5): 433-9. 
153. Tabaraee E, Ahn J, Bohl DD, Phillips FM, Singh K. Quantification of multifidus atrophy and fatty infiltration following a minimally invasive microdiscectomy. Int J Spine Surg. 2015;9:25.

154. Teichtahl AJ, Urquhart DM, Wang Y, Wluka AE, Wijethilake P, O'Sullivan R, et al. Fat infiltration of paraspinal muscles is associated with low back pain, disability, and structural abnormalities in community-based adults. Spine J. 2015;15(7):1593-601

155. Teichtahl AJ, Urquhart DM, Wang Y, Wluka AE, O'Sullivan R, Jones G, et al. Physical inactivity is associated with narrower lumbar intervertebral discs, high fat content of paraspinal muscles and low back pain and disability. Arthritis Res Ther. 2015;17:114.

156. Teyhen DS, Childs JD, Stokes MJ, Wright AC, Dugan JL, George SZ. Abdominal and lumbar multifidus muscle size and symmetry at rest and during contracted States. Normative reference ranges. J Ultrasound Med. 2012;31(7):1099-110

157. Urrutia J, Besa P, Lobos D, Andia M, Arrieta C, Uribe S. Is a single-level measurement of paraspinal muscle fat infiltration and cross-sectional area representative of the entire lumbar spine? Skelet Radiol. 2018;47(7):939-45.

158. Van K, Hides JA, Richardson CA. The use of real-time ultrasound imaging for biofeedback of lumbar multifidus muscle contraction in healthy subjects. J Orthop Sports Phys Ther. 2006:36(12):920-5.

159. Wallwork TL, Hides JA, Stanton WR. Intrarater and interrater reliability of assessment of lumbar multifidus muscle thickness using rehabilitative ultrasound imaging. J Orthop Sports Phys Ther. 2007;37(10):608-12.

160. Wallwork TL, Stanton WR, Freke M, Hides JA. The effect of chronic low back pain on size and contraction of the lumbar multifidus muscle. Man Ther. 2009;14(5):496-500.

161. Wan Q, Lin C, Li X, Zeng W, Ma C. MRI assessment of paraspinal muscles in patients with acute and chronic unilateral low back pain. Br J Radiol. 2015; 88(1053):20140546

162. Watanabe K, Ohashi M, Hirano T, Katsumi K, Shoji H, Mizouchi T, et al. The influence of lumbar muscle volume on curve progression after skeletal maturity in patients with adolescent idiopathic scoliosis: A long-term followup study. Spine Deform. 2018.

163. Wilson A, Hides JA, Blizzard L, Callisaya M, Cooper A, Srikanth VK, et al. Measuring ultrasound images of abdominal and lumbar multifidus muscles in older adults: A reliability study. Man Ther. 2016;23:114-9.

164. Worsley PR, Smith N, Warner MB, Stokes M. Ultrasound transducer shape has no effect on measurements of lumbar multifidus muscle size. Man Ther. 2012;17(2):187-91.

165. Yagi M, Hosogane N, Watanabe K, Asazuma T, Matsumoto M. The paravertebral muscle and psoas for the maintenance of global spinal alignment in patient with degenerative lumbar scoliosis. Spine J. 2016;16(4): 451-8.

166. Yanik B, Keyik B, Conkbayir I. Fatty degeneration of multifidus muscle in patients with chronic low back pain and in asymptomatic volunteers: quantification with chemical shift magnetic resonance imaging. Skelet Radiol. 2013;42(6):771-8.

167. Zielinski KA, Henry SM, Ouellette-Morton RH, DeSarno MJ. Lumbar multifidus muscle thickness does not predict patients with low back pain who improve with trunk stabilization exercises. Arch Phys Med Rehabil. 2013; 94(6):1132-8.

168. Zotti MGT, Boas FV, Clifton T, Piche M, Yoon WW, Freeman BJC. Does preoperative magnetic resonance imaging of the lumbar multifidus muscle predict clinical outcomes following lumbar spinal decompression for symptomatic spinal stenosis? Eur Spine J. 2017;26(10):2589-97.

169. Azadinia F, Ebrahimi Takamjani I, Kamyab M, Kalbassi G, Sarrafzadeh J, Parnianpour M. The effect of lumbosacral orthosis on the thickness of deep trunk muscles using ultrasound imaging: A randomized controlled trial in patients with chronic low back pain. Am J Phys Med Rehabilit. 2019.

170. Banno T, Arima H, Hasegawa T, Yamato Y, Togawa D, Yoshida G, et al. The effect of paravertebral muscle on the maintenance of upright posture in patients with adult spinal deformity. Spine Deform. 2019;7(1):125-31.

171. Belavy DL, Quittner M, Ridgers ND, Ling Y, Connell D, Trudel G, et al. Beneficial intervertebral disc and muscle adaptations in high-volume road cyclists. Med Sci Sports Exerc. 2019;51(1):211-7.

172. Berry DB, Padwal J, Johnson S, Englund EK, Ward SR, Shahidi B. The effect of high-intensity resistance exercise on lumbar musculature in patients with low back pain: a preliminary study. BMC Musculoskelet Disord. 2019;20(1): 290.
173. Burkhart K, Allaire B, Bouxsein ML. Negative effects of long-duration spaceflight on paraspinal muscle morphology. Spine. 2019;44(12):879-86.

174. Crawford RJ, Volken T, Mhuiris ÁN, Bow CC, Elliott JM, Hoggarth MA, et al. Geography of lumbar paravertebral muscle fatty infiltration: The influence of demographics, low back pain, and disability. Spine. 2019.

175. Emami F, Yoosefinejad AK, Razeghi M. Correlations between core muscle geometry, pain intensity, functional disability and postural balance in patients with nonspecific mechanical low back pain. Med Eng Phys. 2018; 60:39-46.

176. Fortin M, Rizk A, Frenette S, Boily M, Rivaz H. Ultrasonography of multifidus muscle morphology and function in ice hockey players with and without low back pain. Phys Ther Sport. 2019;37:77-85.

177. Hanimoglu H, Cevik S, Yilmaz H, Kaplan A, Calis F, Katar S, et al. Effects of modic type 1 changes in the vertebrae on low back pain. World Neurosurg. 2019:121:e426-e32.

178. Huang CWC, Tseng IJ, Yang SW, Lin YK, Chan WP. Lumbar muscle volume in postmenopausal women with osteoporotic compression fractures: quantitative measurement using MRI. Eur Radiol. 2019.

179. Lindstrom I, Khan N, Vanttinen T, Peltokangas M, Sillanpaa N, Oksala N. Psoas muscle area and quality are independent predictors of survival in patients treated for abdominal aortic aneurysms. Ann Vasc Surg. 2019;56: 183-93 e3.

180. Liu Y, Liu Y, Hai Y, Liu T, Guan L, Chen X. Fat infiltration in the multifidus muscle as a predictor of prognosis after decompression and fusion in patients with single-segment degenerative lumbar spinal stenosis: An ambispective cohort study based on propensity score matching. World Neurosurg. 2019.

181. Mannil M, Burgstaller JM, Thanabalasingam A, Winklhofer S, Betz M, Held U, et al. Texture analysis of paraspinal musculature in MRI of the lumbar spine: analysis of the lumbar stenosis outcome study (LSOS) data. Skeletal Rad. 2018:47(7):947-54

182. Menezes-Reis R, Bonugli GP, Salmon CEG, Mazoroski D, Da Silva Herrero CFP, Nogueira-Barbosa MH. Relationship of spinal alignment with muscular volume and fat infiltration of lumbar trunk muscles. PLoS One. 2018;13(7).

183. Minetto MA, Gamerro G, Gays G, Vigo S, Caresio C, Gorji NE, et al. Effectiveness of an innovative mattress overlay for improving rehabilitation in low back pain: A pilot randomized controlled study. J Back Musculoskelet Rehabil. 2018;31(6):1075-83.

184. Quittner M, Rantalainen T, Ridgers ND, Trudel G, Sheikh A, Connell D, et al. Intervertebral disc status is associated with vertebral marrow adipose tissue and muscular endurance. Eur Spine J. 2018.

185. Rezazadeh F, Taheri N, Okhravi SM, Hosseini SM. The relationship between cross-sectional area of multifidus muscle and disability index in patients with chronic non-specific low back pain. Musculoskel Sci Pract. 2019:42:1-5.

186. Sarafraz H, Hadian MR, Ayoobi Yazdi N, Olyaei G, Bagheri H, Jalaei S, et al. Neuromuscular morphometric characteristics in low back pain with unilateral radiculopathy caused by disc herniation: An ultrasound imaging evaluation. Musculoskelet Sci Pract. 2019;40:80-6.

187. Sadeghi S, Quinlan K, Eilertson KE, Billy GG, Bible J, Sions JM, et al. Changes in shear modulus of the lumbar multifidus muscle during different body positions. J Biomech Eng. 2019;141(8).

188. Shadani A, Mohseni Bandpei MA, Rahmani N, Bassampour SA. A comparison of the abdominal and lumbar multifidus muscle size in patients with lumbar spondylolisthesis and healthy patients at rest and during contraction using ultrasonography. J Manip Physiol Ther. 2018;41(8):691-7.

189. Sions JM, Crippen DC, Hicks GE, Alroumi AM, Manal TJ, Pohlig RT. Exploring neuromuscular electrical stimulation intensity effects on multifidus muscle activity in adults with chronic low back pain: An ultrasound imaginginformed investigation. Clin Med Insights Arthritis Musculoskelet Disord. 2019;12:1179544119849570.

190. Smyers Evanson A, Myrer JW, Eggett DL, Mitchell UH, Johnson AW. Multifidus muscle size and symmetry in ballroom dancers with and without low back pain. Int J Sports Med. 2018.

191. Takashima H, Takebayashi T, Ogon I, Yoshimoto M, Morita T, Imamura R, et al. Analysis of intra and extramyocellular lipids in the multifidus muscle in patients with chronic low back pain using MR spectroscopy. Br J Radiol. 2018;91(1083):20170536.

192. Wagner SC, Sebastian AS, McKenzie JC, Butler JS, Kaye ID, Morrissey PB, et al. Severe lumbar disability is associated with decreased psoas cross-sectional area in degenerative spondylolisthesis. Glob Spine J. 2018;8(7):716-21. 
193. Wesselink E, de Raaij E, Pevenage P, van der Kaay N, Pool J. Fear-avoidance beliefs are associated with a high fat content in the erector spinae: a 1.5 tesla magnetic resonance imaging study. Chiropr Man Ther. 2019;27:14.

194. Alejaldre A, Diaz-Manera J, Ravaglia S, Tibaldi EC, D'Amore F, Moris G, et al. Trunk muscle involvement in late-onset Pompe disease: study of thirty patients. Neuromuscular Dis. 2012;22(Suppl 2):S148-54.

195. Arocho-Quinones EV, Kolimas A, LaViolette PS, Kaufman BA, Foy AB, Zwienenberg $M$, et al. Split laminotomy versus conventional laminotomy: postoperative outcomes in pediatric patients. J Neurosurg Pediatr. 2018; 21(6):615-25.

196. Atci IB, Yilmaz H, Samanci MY, Baran O, Yaman M. Rare case of complete fatty degeneration of the paraspinal muscle in a patient with low back pain. J Clin Analytical Med. 2016;7(2):276-8.

197. Baek SO, Ahn SH, Jones R, Cho HK, Jung GS, Cho YW, et al. Activations of deep lumbar stabilizing muscles by transcutaneous neuromuscular electrical stimulation of lumbar paraspinal regions. Ann Rehabil Med. 2014;38(4):50613

198. Baek SO, Cho HK, Jung GS, Son SM, Cho YW, Ahn SH. Verification of an optimized stimulation point on the abdominal wall for transcutaneous neuromuscular electrical stimulation for activation of deep lumbar stabilizing muscles. Spine J. 2014;14(9):2178-83.

199. Baek SO, Cho HK, Kim SY, Jones R, Cho YW, Ahn SH. Changes in deep lumbar stabilizing muscle thickness by transcutaneous neuromuscular electrical stimulation in patients with low back pain. J Back Musculoskelet Rehabil. 2017;30(1):121-7.

200. Battaglia PJ, Maeda Y, Welk A, Hough B, Kettner N. Reliability of the Goutallier classification in quantifying muscle fatty degeneration in the lumbar multifidus using magnetic resonance imaging. J Manip Physiol Ther. 2014;37(3):190-7.

201. Belavy DL, Hides JA, Wilson SJ, Stanton W, Dimeo FC, Rittweger J, et al. Resistive simulated weightbearing exercise with whole body vibration reduces lumbar spine deconditioning in bed-rest. Spine. 2008;33(5):E121-31.

202. Belavy DL, Armbrecht G, Gast U, Richardson CA, Hides JA, Felsenberg D. Countermeasures against lumbar spine deconditioning in prolonged bed rest: resistive exercise with and without whole body vibration. J Appl Physiol. 2010;109(6):1801-11.

203. Belavy DL, Armbrecht G, Richardson CA, Felsenberg D, Hides JA. Muscle atrophy and changes in spinal morphology: is the lumbar spine vulnerable after prolonged bed-rest? Spine. 2011;36(2):137-45.

204. Brenner AK, Gill NW, Buscema CJ, Kiesel K. Improved activation of lumbar multifidus following spinal manipulation: a case report applying rehabilitative ultrasound imaging. J Orthop Sports Phys Ther. 2007;37(10): 613-9.

205. Campbell WW, Vasconcelos O, Laine FJ. Focal atrophy of the multifidus muscle in lumbosacral radiculopathy. Muscle Nerve. 1998:21(10):1350-3.

206. Chen YY, Pao JL, Liaw CK, Hsu WL, Yang RS. Image changes of paraspinal muscles and clinical correlations in patients with unilateral lumbar spinal stenosis. Eur Spine J. 2014;23(5):999-1006.

207. Chen ZN, Yao XM, Lv Y, He BJ, Ye JC, Shao RX, et al. Morphology of the lumbar multifidus muscle in lumbar disc herniation at different durations and at different ages. Exp Ther Med. 2018;15(5):4119-26.

208. Chung S, Lee J, Yoon J. Effects of stabilization exercise using a ball on mutifidus cross-sectional area in patients with chronic low back pain. Sports Sci Med. 2013;12(3):533-41.

209. Danneels LA, Vanderstraeten GG, Cambier DC, Witvrouw EE, De Cuyper HJ, Danneels L. CT imaging of trunk muscles in chronic low back pain patients and healthy control subjects. Eur Spine J. 2000;9(4):266-72.

210. Danneels L, Cagnie B, D'hooge R, de Deene Y, Crombez G, Vanderstraeten $\mathrm{G}$, et al. The effect of experimental low back pain on lumbar muscle activity in people with a history of clinical low back pain: A muscle functional MRI study. J Neurophysiol. 2016;115(2):851-7.

211. De Ridder EM, Van Oosterwijck JO, Vleeming A, Vanderstraeten GG, Danneels LA. Muscle functional MRI analysis of trunk muscle recruitment during extension exercises in asymptomatic individuals. Scand J Med Sci Sports. 2015;25(2):196-204

212. Debuse D, Birch O, St Clair Gibson A, Caplan N. Low impact weightbearing exercise in an upright posture increases the activation of two key local muscles of the lumbo-pelvic region. Physiother Theory Pract. 2013;29(1):51-60.
213. Dickx N, Cagnie B, Parlevliet T, Lavens A, Danneels L. The effect of unilateral muscle pain on recruitment of the lumbar multifidus during automatic contraction. An experimental pain study. Man Ther. 2010;15(4):364-9.

214. Djordjevic O, Djordjevic A, Konstantinovic L. Interrater and intrarater reliability of transverse abdominal and lumbar multifidus muscle thickness in subjects with and without low back pain. J Orthop Sports Phys Ther. 2014;44(12):979-88.

215. Dreyfuss P, Stout A, Aprill C, Pollei S, Johnson B, Bogduk N. The significance of multifidus atrophy after successful radiofrequency neurotomy for low back pain. PM R. 2009;1(8):719-22.

216. Ekin EE, Kurtul Yildiz H, Mutlu H. Age and sex-based distribution of lumbar multifidus muscle atrophy and coexistence of disc hernia: an MRI study of 2028 patients. Diagn Interv Radiol. 2016;22(3):273-6.

217. Fischer MA, Nanz D, Shimakawa A, Schirmer T, Guggenberger R, Chhabra A, et al. Quantification of muscle fat in patients with low back pain: comparison of multi-echo MR imaging with single-voxel MR spectroscopy. Radiology. 2013;266(2):555-63.

218. Fortin M, Videman T, Gibbons LE, Battie MC. Paraspinal muscle morphology and composition: a 15-yr longitudinal magnetic resonance imaging study. Med Sci Sports Exerc. 2014;46(5):893-901.

219. Fortin M, LazÃiry Ã, Varga PP, MC BÃ. Association between paraspinal muscle morphology, clinical symptoms and functional status in patients with lumbar spinal stenosis. Eur Spine J. 2017;26(10):2543-51.

220. Goubert D, De Pauw R, Meeus M, Willems T, Cagnie B, Schouppe S, et al. Lumbar muscle structure and function in chronic versus recurrent low back pain: a cross-sectional study. Spine J. 2017;17(9):1285-96.

221. Hides JA, Stanton WR. Predicting football injuries using size and ratio of the multifidus and quadratus lumborum muscles. Scand J Med Sci Sports. 2017; 27(4):440-7.

222. Hides JA, Richardson CA, Jull GA. Magnetic resonance imaging and ultrasonography of the lumbar multifidus muscle. Comparison of two different modalities. Spine. 1995;20(1):54-8.

223. Hides JA, Lambrecht G, Richardson CA, Stanton WR, Armbrecht G, Pruett C, et al. The effects of rehabilitation on the muscles of the trunk following prolonged bed rest. Eur Spine J. 2011;20(5):808-18.

224. Hussein M, Hussein T. Effect of autologous platelet leukocyte rich plasma injections on atrophied lumbar multifidus muscle in low back pain patients with monosegmental degenerative disc disease. Sicot J. 2016;2:12.

225. Kanchiku T, Imajo Y, Suzuki H, Yoshida Y, Nishida N, Taguchi T. Percutaneous radiofrequency facet joint denervation with monitoring of compound muscle action potential of the multifidus muscle group for treating chronic low back pain: a preliminary report. J Spinal Dis Techniques. 2014;27(7): E262-7.

226. Koppenhaver SL, Parent EC, Teyhen DS, Hebert JJ, Fritz JM. The effect of averaging multiple trials on measurement error during ultrasound imaging of transversus abdominis and lumbar multifidus muscles in individuals with low back pain. J Orthop Sports Phys Ther. 2009;39(8):604-11.

227. Koppenhaver SL, Fritz JM, Hebert JJ, Kawchuk GN, Childs JD, Parent EC, et al. Association between changes in abdominal and lumbar multifidus muscle thickness and clinical improvement after spinal manipulation. J Orthop Sports Phys Ther. 2011:41(6):389-99.

228. Larrie-Baghal M, Bakhtiary AH, Rezasoltani A, Hedayati R, Ghorbani R. Multiplying linear dimension techniques may predict the cross-sectional area of multifidus muscle at all levels of lumbar spine. J Back Musculoskelet Rehabil. 2012;25(3):171-6.

229. Lee SW, Chan CK, Lam TS, Lam C, Lau NC, Lau RW, et al. Relationship between low back pain and lumbar multifidus size at different postures. Spine. 2006;31(19):2258-62.

230. Mayer JM, Nuzzo JL. Worksite back and core exercise in firefighters: Effect on development of lumbar multifidus muscle size. Work. 2015;50(4):621-7.

231. Mangum LC, Sutherlin MA, Saliba SA, Hart JM. Reliability of ultrasound imaging measures of transverse abdominis and lumbar multifidus in various positions. PM R. 2016;8(4):340-7.

232. McKiernan $S$, Chiarelli $P$, Warren-Forward $H$. The content of a training package in diagnostic ultrasound for physiotherapists. Sonography. 2015; 2(1):1-7.

233. Nabavi N, Mosallanezhad Z, Haghighatkhah HR, Ali Mohseni Bandpeid M. Reliability of rehabilitative Ultrasonography to measure transverse abdominis and multifidus muscle dimensions. Iran J Radiol. 2014;11(3). 
234. Nuzzo JL, Mayer JM. Body mass normalisation for ultrasound measurements of lumbar multifidus and abdominal muscle size. Man Ther. 2013;18(3):237-42.

235. Nuzzo JL, Haun DW, Mayer JM. Ultrasound measurements of lumbar multifidus and abdominal muscle size in firefighters. J Back Musculoskelet Rehabil. 2014;27(4):427-33.

236. Partner SL, Sutherlin MA, Acocello S, Saliba SA, Magrum EM, Hart JM. Changes in muscle thickness after exercise and biofeedback in people with low back pain. J Sport Rehabil. 2014;23(4):307-18.

237. Scott IR, Vaughan ARS, Hall J. Swiss ball enhances lumbar multifidus activity in chronic low back pain. Phys Ther Sport. 2015;16(1):40-4.

238. Sebro R, O'Brien L, Torriani M, Bredella MA. Assessment of trunk muscle density using $C T$ and its association with degenerative disc and facet joint disease of the lumbar spine. Skelet Radiol. 2016;45(9):1221-6.

239. Seung JH, Young BK, Yang SK, Seung WP, Taek KN, Hyun JH, et al. Postoperative changes in paraspinal muscle volume: Comparison between paramedian interfascial and midline approaches for lumbar fusion. J Korean Med Sci. 2007;22(4):646-51.

240. Shafaq N, Suzuki A, Matsumura A, Terai H, Toyoda H, Yasuda H, et al. Asymmetric degeneration of paravertebral muscles in patients with degenerative lumbar scoliosis. Spine. 2012;37(16):1398-406

241. Shahidi B, Parra CL, Berry DB, Hubbard JC, Gombatto S, Zlomislic V, et al. Contribution of lumbar spine pathology and age to paraspinal muscle size and fatty infiltration. Spine. 2017:42(8):616-23.

242. Shahtahmassebi B, Hebert JJ, Hecimovich MD, Fairchild TJ. Associations between trunk muscle morphology, strength and function in older adults. Sci Rep. 2017;7(1):10907.

243. Stokes MJ, Cooper RG, Morris G, Jayson MIV. Selective changes in multifidus dimensions in patients with chronic low back pain. Eur Spine J. 1992;1(1): 38-42.

244. Tonomura H, Hatta Y, Mikami Y, Ikeda T, Harada T, Nagae M, et al. Magnetic resonance imaging evaluation of the effects of surgical invasiveness on paravertebral muscles after Muscle-preserving Interlaminar Decompression (MILD). Clin Spine Surg. 2017;30(2):E76-e82.

245. Urrutia J, Besa P, Lobos D, Campos M, Arrieta C, Andia M, et al. Lumbar paraspinal muscle fat infiltration is independently associated with sex, age, and inter-vertebral disc degeneration in symptomatic patients. Skelet Radiol. 2018:47(7):955-61.

246. Valentin S, Licka T, Elliott J. Age and side-related morphometric MRI evaluation of trunk muscles in people without back pain. Man Ther. 2015: 20(1):90-5.

247. Valentin S, Yeates TD, Licka T, Elliott J. Inter-rater reliability of trunk muscle morphometric analysis. J Back Musculoskelet Rehabil. 2015;28(1):181-90.

248. Watson T, McPherson S, Starr K. The association of nutritional status and gender with cross-sectional area of the multifidus muscle in establishing normative data. J Man Manipulative Ther. 2008;16(4):E93-8.

249. Willemink MJ, van Es HW, Helmhout PH, Diederik AL, Kelder JC, van Heesewijk JP. The effects of dynamic isolated lumbar extensor training on lumbar multifidus functional cross-sectional area and functional status of patients with chronic nonspecific low back pain. Spine. 2012;37(26):E1651-8.

250. Winslow J, Getzin A, Greenberger $H$, Silbert W. Fatty infiltrate of the lumbar multifidus muscles predicts return to play in young athletes with extensionbased low back pain. Clin J Sport Med. 2017

251. Wong AY, Parent EC, Kawchuk GN. Reliability of 2 ultrasonic imaging analysis methods in quantifying lumbar multifidus thickness. J Orthop Sports Phys Ther. 2013;43(4):251-62

252. Woodham M, Woodham A, Skeate JG, Freeman M. Long-term lumbar multifidus muscle atrophy changes documented with magnetic resonance imaging: a case series. J Radiol Case Rep. 2014;8(5):27-34.

253. Aboufazeli M, Akbari M, Jamshidi AA, Jafarpisheh MS. Comparison of selective local and global muscle thicknesses in females with and without chronic low back pain. Ortopedia Traumatol Rehabilitacja. 2018; 20(3):197-204

254. Agten A, Verbrugghe J, Stevens S, Boomgaert L, B OE, Timmermans A, et al. Feasibility, accuracy and safety of a percutaneous fine-needle biopsy technique to obtain qualitative muscle samples of the lumbar multifidus and erector spinae muscle in persons with low back pain. J Anat. 2018; 233(4):542-51.

255. Creze M, Bedretdinova D, Soubeyrand M, Rocher L, Gennisson JL, Gagey O, et al. Posture-related stiffness mapping of paraspinal muscles. J Anat. 2019; 234(6):787-99.
256. Izumoto $Y$, Kurihara T, Suga T, Isaka T. Bilateral differences in the trunk muscle volume of skilled golfers. PLoS One. 2019;14(4):e0214752.

257. Lorbergs AL, Allaire BT, Yang L, Kiel DP, Cupples LA, Jarraya M, et al. A longitudinal study of trunk muscle properties and severity of thoracic kyphosis in women and men: The Framingham Study. J Gerontol A Biol Sci Med Sci. 2018.

258. Murillo C, Falla D, Sanderson A, Rushton A, Heneghan NR. Shear wave elastography investigation of multifidus stiffness in individuals with low back pain. J Electromyogr Kinesiol. 2019;47:19-24.

259. Pishnamaz M, Schemmann U, Herren C, Horst K, Hildebrand F, Kobbe P, et al. Limitations in clinical outcome after posterior stabilization of thoracolumbar fractures do not correlate with dynamic trunk muscle dysfunction: an ultrasound controlled prospective cohort study. Eur J Med Res. 2018;23(1):26

260. Xiao Y, Fortin M, Battie MC, Rivaz H. Population-averaged MRI atlases for automated image processing and assessments of lumbar paraspinal muscles. Eur Spine J. 2018:27(10):2442-8.

261. Xie D, Zhang J, Ding W, Yang S, Yang D, Ma L, et al. Abnormal change of paravertebral muscle in adult degenerative scoliosis and its association with bony structural parameters. Eur Spine J. 2019.

262. Yaltirik K, Gudu BO, Isik Y, Altunok C, Tipi U, Atalay B. Volumetric muscle measurements indicate significant muscle degeneration in single-level disc herniation patients. World Neurosurg. 2018.

263. Yoshiko A, Kaji T, Sugiyama H, Koike T, Oshida Y, Akima H. Muscle quality characteristics of muscles in the thigh, upper arm and lower back in elderly men and women. Eur J Appl Physiol. 2018;118(7):1385-95.

264. Yurdakul OV, Beydoğan E, Yalçınkaya EY. Effects of physical therapy agents on pain, disability, quality of life, and lumbar paravertebral muscle stiffness via elastography in patients with chronic low back pain. Turk J Phys Med Rehabil. 2019:65(1):30-9.

265. Zhang Y, Zhou Z, Wang C, Cheng X, Wang L, Duanmu Y, et al. Reliability of measuring the fat content of the lumbar vertebral marrow and paraspinal muscles using MRI mDIXON-Quant sequence. Diagn Interv Radiol. 2018; 24(5):302-7.

266. Zhu HF, Wang GL, Zhou ZJ, Fan SW. Prospective study of long-term effect between multifidus muscle bundle and conventional open approach in onelevel posterior lumbar interbody fusion. Orthop Surg. 2018;10(4):296-305.

267. Akgul O, Gulkesen A, Akgol G, Ozgocmen S. MR-defined fat infiltration of the lumbar paravertebral muscles differs between non-radiographic axial spondyloarthritis and established ankylosing spondylitis. Mod Rheumatol. 2013;23(4):811-6.

268. Anaya A, Plantmason L, Dhaliwal G. Back attack. J Gen Intern Med. 2014; 29(1):255-9.

269. Barker KL, Shamley DR, Jackson D. Changes in the cross-sectional area of multifidus and psoas in patients with unilateral back pain: the relationship to pain and disability. Spine. 2004;29(22):E515-9.

270. Bouche KGW, Vanovermeire O, Stevens VK, Coorevits PL, Caemaert J J, Cambier DC, et al. Computed tomographic analysis of the quality of trunk muscles in asymptomatic and symptomatic lumbar discectomy patients. BMC Musculoskelet Disord. 2011;12

271. Cai C, Kong PW. Low back and lower-limb muscle performance in male and female recreational runners with chronic low back pain. J Orthop Sports Phys Ther. 2015:45(6):436-43.

272. Fan SW, Hu ZJ, Fang XQ, Zhao FD, Huang Y, Yu HJ. Comparison of paraspinal muscle injury in one-level lumbar posterior inter-body fusion: modified minimally invasive and traditional open approaches. Orthop Surg. 2010;2(3):194-200.

273. Gala-Alarcon P, Calvo-Lobo C, Serrano-Imedio A, Garrido-Marin A, MartinCasas P, Plaza-Manzano G. Ultrasound evaluation of the abdominal wall and lumbar multifidus muscles in participants who practice pilates: A 1-year follow-up case series. J Manip Physiol Ther. 2018.

274. Gilbert F, Heintel TM, Jakubietz MG, KÃstler H, Sebald C, Meffert RH, et al. Quantitative MRI comparison of multifidus muscle degeneration in thoracolumbar fractures treated with open and minimally invasive approach. BMC Musculoskelet Disord. 2018;19(1)

275. Hadar H, Gadoth N, Heifetz M. Fatty replacement of lower paraspinal muscles: normal and neuromuscular disorders. AJR Am J Roentgenol. 1983; 141(5):895-8.

276. Han JS, Ahn JY, Goel VK, Takeuchi R, McGowan D. CT-based geometric data of human spine musculature. Part I. Japanese patients with chronic low back pain. J Spinal Disord. 1992;5(4):448-58 
277. Hides JA, Stanton WR, Mendis MD, Gildea J, Sexton MJ. Effect of motor control training on muscle size and football games missed from injury. Med Sci Sports Exerc. 2012;44(6):1141-9.

278. Hildebrandt M, Fankhauser G, Meichtry A, Luomajoki H. Correlation between lumbar dysfunction and fat infiltration in lumbar multifidus muscles in patients with low back pain. BMC Musculoskelet Disord. 2017;18(1):12.

279. Hung CW, Wu MF, Hong RT, Weng MJ, Yu GF, Kao CH. Comparison of multifidus muscle atrophy after posterior lumbar interbody fusion with conventional and cortical bone trajectory. Clin Neurol Neurosurg. 2016;145: $41-5$.

280. Junhui L, Zhengbao P, Wenbin X, Lu H, Shengyun L, Shunwu F, et al. Comparison of pedicle fixation by the Wiltse approach and the conventional posterior open approach for thoracolumbar fractures, using $\mathrm{MRI}$, histological and electrophysiological analyses of the multifidus muscle. Eur Spine J. 2017;26(5):1506-14.

281. Kalichman L, Hodges P, Li L, Guermazi A, Hunter DJ. Changes in paraspinal muscles and their association with low back pain and spinal degeneration: CT study. Eur Spine J. 2010;19(7):1136-44.

282. Kim DY, Lee SH, Chung SK, Lee HY. Comparison of multifidus muscle atrophy and trunk extension muscle strength: percutaneous versus open pedicle screw fixation. Spine. 2005;30(1):123-9.

283. Kim H, Lee CK, Yeom JS, Lee JH, Cho JH, Shin Sl, et al. Asymmetry of the cross-sectional area of paravertebral and psoas muscle in patients with degenerative scoliosis. Eur Spine J. 2013;22(6):1332-8.

284. Koppenhaver S, Kniss J, Lilley D, Oates M, FernÃndez-de-las-PeÃas C, Maher $R$, et al. Reliability of ultrasound shear-wave elastography in assessing low back musculature elasticity in asymptomatic individuals. J Electromyogr Kinesiol. 2018;39:49-57.

285. MacDonald D, Moseley GL, Hodges PW. Why do some patients keep hurting their back? Evidence of ongoing back muscle dysfunction during remission from recurrent back pain. Pain. 2009;142(3):183-8.

286. Skeie EJ, Borge JA, Leboeuf-Yde C, Bolton J, Wedderkopp N. Reliability of diagnostic ultrasound in measuring the multifidus muscle. Chiropractic Man Ther. 2015;23:15

287. Sugawara K, Katayose M, Watanabe K. The variation in the lumbar facet joint orientation in an adult Asian population and its relationship with the crosssectional area of the multifidus and erector spinae. Asian Spine J. 2016;10(5): 886-92.

288. Tucker KJ, Fels M, Walker SR, Hodges PW. Comparison of location, depth, quality, and intensity of experimentally induced pain in 6 low back muscles. Clin J Pain. 2014;30(9):800-8.

289. Wiltse LL, Spencer CW. New uses and refinements of the paraspinal approach to the lumbar spine. Spine. 1988;13(6):696-706.

290. Andersen K, Baardsen R, Dalen I, Larsen JP. Impact of exercise programs among helicopter pilots with transient LBP. BMC Musculoskelet Disord. 2017;18(1):269.

291. Arts M, Brand R, van der Kallen B, à Nijeholt GL, Peul W. Does minimally invasive lumbar disc surgery result in less muscle injury than conventional surgery? A randomized controlled trial. Eur Spine J 2011;20(1):51-57.

292. Bae SH, Lee HG, Kim YE, Kim GY, Jung HW, Kim KY. Effects of trunk stabilization exercises on different support surfaces on the cross-sectional area of the trunk muscles and balance ability. J Phys Ther Sci. 2013;25(6): 741-5.

293. Bailey JF, Miller SL, Khieu K, O'Neill CW, Healey RM, Coughlin DG, et al. From the international space station to the clinic: how prolonged unloading may disrupt lumbar spine stability. Spine J. 2018;18(1):7-14.

294. Chan ST, Fung PK, Ng NY, Ngan TL, Chong MY, Tang CN, et al. Dynamic changes of elasticity, cross-sectional area, and fat infiltration of multifidus at different postures in men with chronic low back pain. Spine J. 2012;12(5): 381-8.

295. Haig AJ, Harris A, Quint DJ. Baastrup's disease correlating with diffuse lumbar paraspinal atrophy: a case report. Arch Phys Med Rehabil. 2001;82(2): 250-2.

296. Hebert J, Koppenhaver S, Fritz J, Parent E. Clinical prediction for success of interventions for managing low back pain. Clin Sports Me. 2008; 27(3):463-79.

297. Hebert JJ, Kjaer P, Fritz JM, Walker BF. The relationship of lumbar multifidus muscle morphology to previous, current, and future low back pain: A 9-year population-based prospective cohort study. Spine. 2014; 39(17):1417-25
298. Hebert JJ, Koppenhaver SL, Teyhen DS, Walker BF, Fritz JM. The evaluation of lumbar multifidus muscle function via palpation: Reliability and validity of a new clinical test. Spine J. 2015;15(6):1196-202.

299. Hides JA, Richardson CA, Jull GA. Multifidus muscle recovery is not automatic after resolution of acute, first-episode low back pain. Spine. 1996; 21(23):2763-9.

300. Hides JA, Richardson CA, Jull GA. Use of real-time ultrasound imaging for feedback in rehabilitation. Manual Ther. 1998;3(3):125-31.

301. Kim CY, Choi JD, Kim SY, Oh DW, Kim JK, Park JW. Comparison between muscle activation measured by electromyography and muscle thickness measured using ultrasonography for effective muscle assessment. J Electromyogr Kinesiol. 2014;24(5):614-20.

302. Niemelainen R, Briand MM, Battie MC. Substantial asymmetry in paraspinal muscle cross-sectional area in healthy adults questions its value as a marker of low back pain and pathology. Spine. 2011;36(25):2152-7.

303. Olivier B, Gillion N, Stewart AV, McKinon W. Reduced nondominant lumbar multifidi cross-sectional area is a precursor of low back injury in cricket fast bowlers. Scand J Med Sci Sports. 2017;27(12):1927-33.

304. Vasseljen O, Dahl HH, Mork PJ, Torp HG. Muscle activity onset in the lumbar multifidus muscle recorded simultaneously by ultrasound imaging and intramuscular electromyography. Clin Biomech. 2006;21(9):905-13.

305. Wachi M, Suga T, Higuchi T, Misaki J, Tsuchikane R, Tanaka D, et al. Applicability of ultrasonography for evaluating trunk muscle size: a pilot study. J Phys Ther Sci. 2017;29(2):245-9.

306. Briani RV, Waiteman MC, de Albuquerque CE, Gasoto E, Segatti G, Oliveira $\mathrm{CB}$, et al. Lower trunk muscle thickness is associated with pain in women with patellofemoral pain. J Ultrasound Med. 2019.

307. Claus AP, Hides JA, Moseley GL, Hodges PW. Different ways to balance the spine in sitting: Muscle activity in specific postures differs between individuals with and without a history of back pain in sitting. Clin Biomech. 2018;52:25-32.

308. Cuellar WA, Blizzard L, Hides JA, Callisaya ML, Jones G, Cicuttini F, et al. Vitamin D supplements for trunk muscle morphology in older adults: secondary analysis of a randomized controlled trial. J Cachexia Sarcopenia Muscle. 2019;10(1):177-87.

309. Finta R, Nagy E, Bender T. The effect of diaphragm training on lumbar stabilizer muscles: a new concept for improving segmental stability in the case of low back pain. J Pain Res. 2018;11:3031-45.

310. Harper KD, Phillips D, Lopez JM, Sardar Z. Acute traumatic thoracolumbar paraspinal compartment syndrome: case report. J Neurosurg Spine. 2018; 30(1):140-5.

311. Kim H, Kwon BS, Park JW, Lee H, Nam K, Park T, et al. Effect of whole body horizontal vibration exercise in chronic low back pain patients: vertical versus horizontal vibration exercise. Ann Rehabil Med. 2018;42(6):804-13.

312. Masaki M, Ji X, Yamauchi T, Tateuchi H, Ichihashi N. Effects of the trunk position on muscle stiffness that reflects elongation of the lumbar erector spinae and multifidus muscles: an ultrasonic shear wave elastography study. Eur J Appl Physiol. 2019;119(5):1085-91.

313. Ozcan-Eksi EE, Eksi MS, Akcal MA. Severe lumbar intervertebral disc degeneration is associated with modic changes and fatty infiltration in the paraspinal muscles at all lumbar levels, except for L1-L2: A cross-sectional analysis of 50 symptomatic women and 50 age-matched symptomatic men. World Neurosurg. 2019;122:e1069-e77.

314. Rahmani N, Kiani A, Mohseni-Bandpei M, Abdollahi I. Multifidus muscle size in adolescents with and without back pain using ultrasonography. J Bodyw Mov Ther. 2018;22(1):147-51.

315. Sarafraz H, Hadian MR, Ayoobi Yazdi N, Olyaei G, Bagheri H, Jalaie S, et al. Test-retest reliability of nerve and muscle morphometric characteristics utilizing ultrasound imaging in individuals with unilateral sciatica and controls. Chiropractic Man Ther. 2018;26:47.

316. Shan J, Du P, Zhang Z, Ren D. Approaching the interspace between multifidus and longissimus accurately in lumbar surgery: An anatomically based study of the wiltse approach. Int J Clin Exp Med. 2018;11(8):7770-4

317. Akbari A, Khorashadizadeh S, Abdi G. The effect of motor control exercise versus general exercise on lumbar local stabilizing muscles thickness: Randomized controlled trial of patients with chronic low back pain. J Back Musculoskelet Rehabil. 2008;21(2):105-12.

318. Berglund L, Aasa B, Michaelson P, Aasa U. Effects of low-load motor control exercises and a high-load lifting exercise on lumbar multifidus thickness. Spine. 2017:42(15):E876-E82. 
319. Hosseinifar M, Akbari M, Behtash $H$, Amiri M, Sarrafzadeh J. The effects of stabilization and mckenzie exercises on transverse abdominis and multifidus muscle thickness, pain, and disability: a randomized controlled trial in nonspecific chronic low back pain. J Phys Ther Sci. 2013;25(12):1541-5.

320. Hosseinifar M, Akbari A, Ghiasi F. Intra-rater reliability of rehabilitative ultrasound imaging for multifidus muscles thickness and cross section area in healthy subjects. Global J Health Sci. 2015;7(6):354-61.

321. Ikezoe T, Mori N, Nakamura M, Ichihashi N. Effects of age and inactivity due to prolonged bed rest on atrophy of trunk muscles. Eur J Appl Physiol. 2012;112(1):43-8.

322. Joseph LH, Hussain RI, Naicker AS, Htwe O, Pirunsan U, Paungmali A. Pattern of changes in local and global muscle thickness among individuals with sacroiliac joint dysfunction. Hong Kong Physiother J. 2015;33(1):28-33.

323. Kim S, Kim H, Chung J. Effects of spinal stabilization exercise on the crosssectional areas of the lumbar multifidus and psoas major muscles, pain intensity, and lumbar muscle strength of patients with degenerative disc disease. J Phys Ther Sci. 2014;26(4):579-82.

324. Kliziene I, Sipaviciene S, Klizas S, Imbrasiene D. Effects of core stability exercises on multifidus muscles in healthy women and women with chronic low-back pain. J Back Musculoskelet Rehabil. 2015;28(4):841-7.

325. Masaki M, Ikezoe T, Fukumoto Y, Minami S, Aoyama J, Ibuki S, et al. Association of walking speed with sagittal spinal alignment, muscle thickness, and echo intensity of lumbar back muscles in middle-aged and elderly women. Aging Clin Exp Res. 2016;28(3):429-34.

326. Yang HS, Lee YS, Jin SA. Effect of evidence-based trunk stability exercises on the thickness of the trunk muscles. J Phys Ther Sci. 2015;27(2):473-5.

327. Hebert JJ, Le Cara EC, Koppenhaver SL, Hoffman MD, Marcus RL, Dempsey $A R$, et al. Predictors of clinical success with stabilization exercise are associated with lower levels of lumbar multifidus intramuscular adipose tissue in patients with low back pain. Disabil Rehabil. 2018:1-7.

328. Nabavi N, Mohseni Bandpei MA, Mosallanezhad Z, Rahgozar M, Jaberzadeh S. The effect of 2 different exercise programs on pain intensity and muscle dimensions in patients with chronic low back pain: A randomized controlled trial. J Manip Physiol Ther. 2018:41(2):102-10.

329. Shahtahmassebi B, Hebert JJ, Hecimovich M, Fairchild TJ. Trunk exercise training improves muscle size, strength, and function in older adults: A randomized controlled trial. Scand J Med Sci Sports. 2019;29(7):980-91.

330. Hides J, Stanton W, Mendis MD, Sexton M. The relationship of transversus abdominis and lumbar multifidus clinical muscle tests in patients with chronic low back pain. Manual Ther. 2011;16(6):573-7.

331. Huang Q, Li D, Yokotsuka N, Zhang Y, Ubukata H, Huo M, et al. The intervention effects of different treatment for chronic low back pain as assessed by the cross-sectional area of the multifidus muscle. J Phys Ther Sci. 2013;25(7):811-3.

332. Huang Q, Li D, Zhang J, Yang D, Huo M, Maruyama H. Comparison of the efficacy of different long-term interventions on chronic low back pain using the cross-sectional area of the multifidus muscle and the thickness of the transversus abdominis muscle as evaluation indicators. J Phys Ther Sci. 2014; 26(12):1851-4

333. Huang Q, Zhang Y, Li D, Yang D, Huo M, Maruyama $H$. The evaluation of chronic low back pain by determining the ratio of the lumbar multifidus muscle cross-sectional areas of the unaffected and affected sides. J Phys Ther Sci. 2014:26(10):1613-4.

334. Huang Q, Li D, Zhang Y, Hu A, Huo M, Maruyama $H$. The reliability of rehabilitative ultrasound imaging of the cross-sectional area of the lumbar multifidus muscles in the PNF pattern. J Phys Ther Sci. 2014;26(10):1539-41.

335. Ikezoe T, Nakamura M, Shima H, Asakawa Y, Ichihashi N. Association between walking ability and trunk and lower-limb muscle atrophy in institutionalized elderly women: a longitudinal pilot study. J Physiol Anthropol. 2015;34:31.

336. Lee SJ, Kim YN, Lee DK. The effect of flexi-bar exercise with vibration on trunk muscle thickness and balance in university students in their twenties. J Phys Ther Sci. 2016;28(4):1298-302.

337. Noormohammadpour $P$, Hosseini Khezri A, Linek P, Mansournia MA Hassannejad A, Younesian A, et al. Comparison of lateral abdominal muscle thickness and cross sectional area of multifidus in adolescent soccer players with and without low back pain: A case control study. Asian J Sports Med. 2016;7(4):e38318.

338. Rahmani N, Kiani A, Mohseni-Bandpei MA, Abdollahi I. Multifidus muscle size in adolescents with and without back pain using ultrasonography. J Bodyw Mov Ther. 2018;22(1):147-51.
339. Rostami M, Noormohammadpour P, Sadeghian AH, Mansournia MA, Kord $R$. The effect of lumbar support on the ultrasound measurements of trunk muscles: a single-blinded randomized controlled trial. PM R. 2014;6(4):302-8 quiz 8 .

340. Tsuchikane R, Higuchi T, Suga T, Wachi M, Misaki J, Tanaka D, et al. Relationships between bat swing speed and muscle thickness and asymmetry in collegiate baseball players. Sports. 2017;5(2).

341. Hwang YI, Park DJ. Comparison of lumbar multifidus thickness and perceived exertion during graded superman exercises with or without an abdominal drawing-in maneuver in young adults. J Exerc Rehabil. 2018, 14(4):628-32.

342. Rutkowska-Kucharska A, Szpala A. The use of electromyography and magnetic resonance imaging to evaluate a core strengthening exercise programme. J Back Musculoskelet Rehabil. 2018;31(2):355-62.

343. Tandon R, Kiyawat V, Kumar N. Clinical correlation between muscle damage and oswestry disability index score after open lumbar surgery: Does open surgery reduces functional ability? Asian Spine J. 2018;12(3):518-23.

\section{Publisher's Note}

Springer Nature remains neutral with regard to jurisdictional claims in published maps and institutional affiliations.

Ready to submit your research? Choose BMC and benefit from:

- fast, convenient online submission

- thorough peer review by experienced researchers in your field

- rapid publication on acceptance

- support for research data, including large and complex data types

- gold Open Access which fosters wider collaboration and increased citations

- maximum visibility for your research: over $100 \mathrm{M}$ website views per year

At BMC, research is always in progress.

Learn more biomedcentral.com/submissions 